\title{
Molecular prevalence and risk factors associated with tick-borne pathogens in cattle in western Kenya
}

\author{
Tatenda Chiuya ${ }^{1}, 2^{*}$, Jandouwe Villinger ${ }^{1}$, Daniel K. Masiga' ${ }^{1}$, Dickens O. Ondifu ${ }^{1}$, Maurice K. Murungi ${ }^{3}$, \\ Lillian Wambua ${ }^{3}$, Armanda D. S. Bastos ${ }^{2}$, Eric M. Fèvre ${ }^{3,4}$ and Laura C. Falzon $3,4^{*}$
}

\begin{abstract}
Background: Tick-borne pathogens (TBPs) are of global importance, especially in sub-Saharan Africa where they represent a major constraint to livestock production. Their association with human disease is also increasingly recognized, signalling their zoonotic importance. It is therefore crucial to investigate TBPs prevalence in livestock populations and the factors associated with their presence. We set out to identify TBPs present in cattle and to determine associated risk factors in western Kenya, where smallholder livestock production is important for subsistence and market-driven income.
\end{abstract}

Results: Tick-borne pathogen infections in blood samples collected from cattle at livestock markets and slaughterhouses between May 2017 and January 2019 were identified by high-resolution melting analysis and sequencing of PCR products of genus-specific primers. Of the 422 cattle sampled, 30.1\% (127/422) were infected with at least one TBP, while 8.8\% (37/422) had dual infections. Anaplasma spp. (19.7\%) were the most prevalent, followed by Theileria (12.3\%), Ehrlichia (6.6\%), and Babesia (0.2\%) spp. Sequence analysis of the TBPs revealed them to be Anaplasma platys-like organisms (13.5\%), Theileria velifera (7.4\%), Anaplasma marginale (4.9\%), Theileria mutans (3.1\%), Theileria parva (1.6\%), and Babesia bigemina (0.2\%). Ehrlichia ruminantium, Rickettsia spp., and arboviruses were not detected. Exotic breeds of cattle were more likely to be infected with A. marginale compared to local breeds (OR: 7.99, 95\% Cl: 3.04-22.02, $p<0.001$ ). Presence of ticks was a significant predictor for Anaplasma spp. (OR: 2.18, 95\% Cl: 1.32-3.69, $p=0.003)$ and Ehrlichia spp. (OR: $2.79,95 \% \mathrm{Cl}: 1.22-7.23, p=0.022)$ infection. Cattle sampled at slaughterhouses were more likely to be positive for Anaplasma spp. (OR: 1.64, 95\% Cl: $1.01-2.70, p=0.048)$ and A. marginale (OR: $3.84,95 \%$ Cl: $1.43-12.21, p=0.012$ ), compared to those sampled at livestock markets.

Conclusion: This study reports TBP prevalence and associated risk factors in western Kenya, factors which are key to informing surveillance and control measures.

Keywords: Livestock markets, Slaughterhouses, Dual infection, Anaplasma, Theileria, Western Kenya

*Correspondence: tchiuya@icipe.org; laura.falzon@liverpool.ac.uk ${ }^{1}$ International Centre of Insect Physiology and Ecology (icipe), P.O Box 30772-00100, Nairobi, Kenya

${ }^{4}$ Institute of Infection, Veterinary and Ecological Sciences, University of Liverpool, Leahurst Campus, Chester High Road, Neston CH64 7TE, UK Full list of author information is available at the end of the article

\section{Background}

Ticks and tick-borne pathogens (TBPs) are constraints to livestock production, causing significant economic losses to the livestock industry in sub-Saharan Africa (SSA) [1]. The major tick vectors in SSA belong to the genera Amblyomma, Rhipicephalus, and Hyalomma, collectively transmitting Babesia, Theileria, Anaplasma, Ehrlichia, Rickettsia, and some viral pathogens [2]. In Kenya, the

(c) The Author(s) 2021. Open Access This article is licensed under a Creative Commons Attribution 4.0 International License, which permits use, sharing, adaptation, distribution and reproduction in any medium or format, as long as you give appropriate credit to the original author(s) and the source, provide a link to the Creative Commons licence, and indicate if changes were made. The images or other third party material in this article are included in the article's Creative Commons licence, unless indicated otherwise in a credit line to the material. If material is not included in the article's Creative Commons licence and your intended use is not permitted by statutory regulation or exceeds the permitted use, you will need to obtain permission directly from the copyright holder. To view a copy of this licence, visit http://creativecommons.org/licenses/by/4.0/. The Creative Commons Public Domain Dedication waiver (http://creativeco mmons.org/publicdomain/zero/1.0/) applies to the data made available in this article, unless otherwise stated in a credit line to the data. 
commonly reported tick-borne diseases (TBDs) associated with livestock production constraints include East Coast fever (Theileria parva: Rhipicephalus appendiculatus), babesiosis (Babesia bigemina: Rhipicephalus decoloratus), anaplasmosis (Anaplasma marginale: Rhipicephalus decoloratus), and heartwater (Ehrlichia ruminantium: Amblyomma variegatum) [3-6]. Other benign Theileria spp., such as Theileria taurotragi, Theileria mutans, and Theileria velifera, are also highly prevalent [7]. Due to their endemic stability in the predominantly indigenous cattle herds in Kenya, most of these TBDs are clinically inapparent. However, exotic breeds introduced into these areas tend to manifest severe clinical diseases due to their poor innate and adaptive immune response to TBPs [8]. Pregnancy or co-infection with other pathogens may also compromise the natural resistance in indigenous cattle, leading to disease manifestation, including weight loss, a drop in milk production, and mortalities $[9,10]$.

While the importance of TBPs in livestock production cannot be understated, an increasing number of reports show that TBPs are zoonotic, thus posing a public health threat [11]. These zoonotic TBPs include protozoa, bacteria, and viruses. Specifically, Babesia divergens and Babesia microti cause human babesiosis, while Ehrlichia chaffeensis and Anaplasma phagocytophilum cause human ehrlichiosis and anaplasmosis, respectively [1, 12, 13]. Recent reports of Anaplasma platys, Anaplasma ovis, and Anaplasma capra in humans suggest that they could be of zoonotic importance [14-16]. The clinical manifestations associated with these pathogens are reported mostly from Europe and North America, and include fever, myalgia and rash [13]. In SSA, Rickettsia africae, which causes African tick bite fever in humans, is common, causing clinical disease in tourists and travellers [17], while only a few cases have been reported in the local population $[18,19]$.

Crimean-Congo haemorrhagic fever (CCHF) virus, transmitted by Hyalomma ticks, is one of the most widespread zoonotic tick-borne viruses globally. Clinical disease in humans is characterised by haemorrhagic fever and a mortality rate of up to $30 \%$ [20]. A single fatal human case of CCHF was reported in western Kenya in 2000 [21], and several outbreaks have been reported in neighbouring Uganda between August 2017 and January 2019, with consequent human fatalities [22]. Moreover, zoonotic Babesia spp., Anaplasma spp., Ehrlichia spp. and Rickettsia spp. have been detected in cattle [23-25], and the CCHF virus was recently detected in $R h$. decoloratus ticks from cattle at slaughterhouses in western Kenya [26]. Given that cattle are carriers of the CCHF virus [27], the role of cattle in the epidemiology of zoonotic TBPs warrants further investigation.
With an estimated 17 million cattle in different production systems, livestock, in addition to its cultural and social value, represent an important source of livelihood in Kenya [28]. In western Kenya alone, there are at least 843,608 and 219,904 indigenous and exotic cattle, respectively [29], yet only a few studies have so far been carried out to assess the prevalence and epidemiology of TBDs constraining livestock production. These studies reported a high seroprevalence of TBDs and associated risk factors in smallholder livestock production systems in the western Kenyan highlands [5] and Machakos County [3, 30, 31], while another study reported that East Coast fever was the major cause of mortality (40\%) in indigenous zebu calves followed from birth to 51 weeks of age in western Kenya [32]. Another study in Lambwe Valley of western Kenya, which represents a wildlife-livestock interface, reported a high animal-level prevalence of TBPs [33], while emerging Anaplasma and Ehrlichia spp. were found to be infecting dairy cows in peri-urban Nairobi [25]. However, the presence of zoonotic TBPs as a measure of risk for human infection in this region has so far received limited attention.

Rising human population and increased demand for human habitation have resulted in increasingly fragmented landscapes and extensive interface areas, facilitating the transmission of zoonotic diseases [34, 35]. The shift to intensive and market-inclined smallholder livestock production systems being witnessed in East Africa is likely to further exacerbate the situation [36]. The livestock markets and slaughterhouses located in peri-urban areas are a conduit for the movement of livestock across internal and country borders in East Africa [37]. Given that animal trade and migration are considered important factors in the introduction and establishment of diseases in new uninfected areas [38], these facilities may be important in the epidemiology of TBDs. Therefore, we carried out this study at livestock markets (LMs) and slaughterhouses (SHs) in western Kenya to determine the prevalence of TBPs in cattle that are of animal and public health concern, using molecular analytical methods. We also determined the presence of co-infections, which may complicate diagnosis and prognosis of TBDs, and assessed which factors are associated with TBP presence in cattle.

\section{Results}

We analyzed 422 cattle blood samples which were collected from seven LMs and SHs between May 2017 and January 2019. Of these, 219 samples were from LMs while 203 were from SHs. Most of the samples were from Kakamega County $(n=272)$ while Bungoma County $(n=99)$ and Busia County $(n=51)$ contributed the remainder. Of these, 50.9\% (215/422) were from female 
cattle while $49.1 \%(207 / 422)$ were from male cattle. The selected samples were comprised of $67.8 \%(286 / 422)$ from local breeds, $17.5 \%$ (74/422) from cross-breed cattle, and $14.7 \%$ (62/422) from exotic breeds. Most (87.4\%; $369 / 422$ ) of the samples were from cattle aged 12 months and above, while $12.6 \%$ (53/422) were from those aged less than 12 months. The body condition score ranged from 1 to 2.5 in $68.5 \%$ (289/422), and from 3 to 5 in 31.5\% $(133 / 422)$ of the cattle. Ticks were noted and collected from 53.3\% (225/422) of these cattle, while they were not observed in the remaining $46.7 \%$ (197/422) of the cattle.

\section{Diversity of TBPs detected by PCR-high resolution melting (HRM) analysis}

We detected Anaplasma spp., Babesia spp., Ehrlichia spp., and Theileria spp. by PCR-HRM among the 422 cattle blood samples analyzed. We however did not detect $E$. ruminantium, Rickettsia spp., or arboviruses. The identifications were based on the distinct HRM profiles and confirmatory sequencing of representative PCR amplicons as shown in Fig. 1.

The phylogeny of representative sequences of pathogens identified in this study is shown in Figs. 2 and 3. The recently described Ehrlichia minasensis detected in this study (GenBank accessions MT672517-MT672518) clustered with $E$. minasensis detected in cattle from Kenya (GenBank accession MT163429) [25] and in Rhipicephalus microplus ticks from Brazil (GenBank accession NR_148800) [39]. Anaplasma marginale strains (GenBank accession MT459306) were closely related to those from Uganda (GenBank accession KU686794) [40], while the Anaplasma centrale strains (GenBank accessions MT459303-MT459304) were closely related to those from China (GenBank accession MF289480) [41]. Our A. platys strains (GenBank accessions MT459319MT459321, MT459326 and MT459328) were closely related to strains previously detected in Kenya (GenBank accession MW019880) [33] and China (GenBank accession MH762081) [42]. We also detected phylogenetically diverse $A$. platys-like sequences that we classified into groups " $A$ " (GenBank accession MT459329) and " $B$ " (GenBank accessions MW663926-MW663928). These clustered within the A. platys clade and shared at least 99\% identity with previously detected $A$. platys (GenBank accession MN266939) [26] and Anaplasma phagocytophilum (GenBank accession MK358051) [43] strains.

Our T. parva strains (GenBank accession MT49411) were closely related to those from South Africa (GenBank accession MK792971) [44], Zambia (GenBank accession MG952926) [45], and Kenya (GenBank MH929322) [46] and (GenBank accession MN294730) [26]. Theileria velifera strains (GenBank accessions MT459436-MT459437) clustered within the same clade as strains from Kenya
(GenBank accession MN853560) [33] and (GenBank accession MN294734) [26], South Africa (GenBank MK792966) [44], and Mozambique (GenBank accession FJ869897) [47]. Theileria mutans strains (GenBank accessions MT704609; MT704611) were closely related to those from Uganda (GenBank KU206320) [48], Kenya (GenBank accessions MN853552 [33] and MN294729 [26]), and South Africa (GenBank accession MK792976) [44]. Babesia bigemina strains (GenBank accession MT459333) were closely related to those from Kenya (GenBank accession MN294720) [26], India (GenBank accession MT322431), and Uganda (GenBank accession KU206297) [48]. All strains of TBPs detected in this study were phylogenetically close to strains of the same pathogens previously detected in ticks collected from the same animals used in this and a prior study [26] (Figs. 2 and 3).

\section{Prevalence of TBPs in cattle based on PCR-HRM analysis}

Of the 422 cattle, 127 (30.1\%) were infected with at least one TBP. Detailed information on the prevalence and infection status of the cattle is shown in Table 1 and Fig. 4. Single infections were detected in 21.3\% (90/422) of the cattle and an additional 8.8\% (37/422) had dual infections.

The most frequent dual infection was a combination of $T$. velifera and the A. platys-like organisms. The most prevalent group was Anaplasma spp. (19.7\%), followed by Theileria (12.3\%), Ehrlichia (6.6\%), and Babesia (0.2\%) spp. Kakamega County had the highest prevalence for most of the pathogens; however, this might have been biased by the selection of the samples analysed, which focused on this county due to prior detection of CCHF virus-positive ticks in a previous study [26]. At species level, detected TBP prevalences were highest for the A. platys clade (13.5\%), T. velifera (7.4\%), A. marginale (4.9\%), and T. mutans (3.1\%), with minor occurrences of other pathogens (Table 1; Fig. 4).

\section{Risk factor analysis}

Logistic regression analysis to determine the association of predictor variables with TBP occurrence was performed at genus level for Anaplasma spp., Ehrlichia spp., and Theileria spp. Species level analysis was only carried out for A. marginale given the lack of sufficient data for the other pathogens. Furthermore, we also prioritized A. marginale due to its economic impact on cattle production in this region. Age as a putative risk factor was excluded from the $A$. marginale analysis due to lack of events in cattle aged less than 12 months.

Tick presence and sampling site were univariably associated with occurrence of Anaplasma spp., while cattle breed and sampling site were univariably associated with Theileria spp. and A. marginale occurrence. Cattle breed 
A
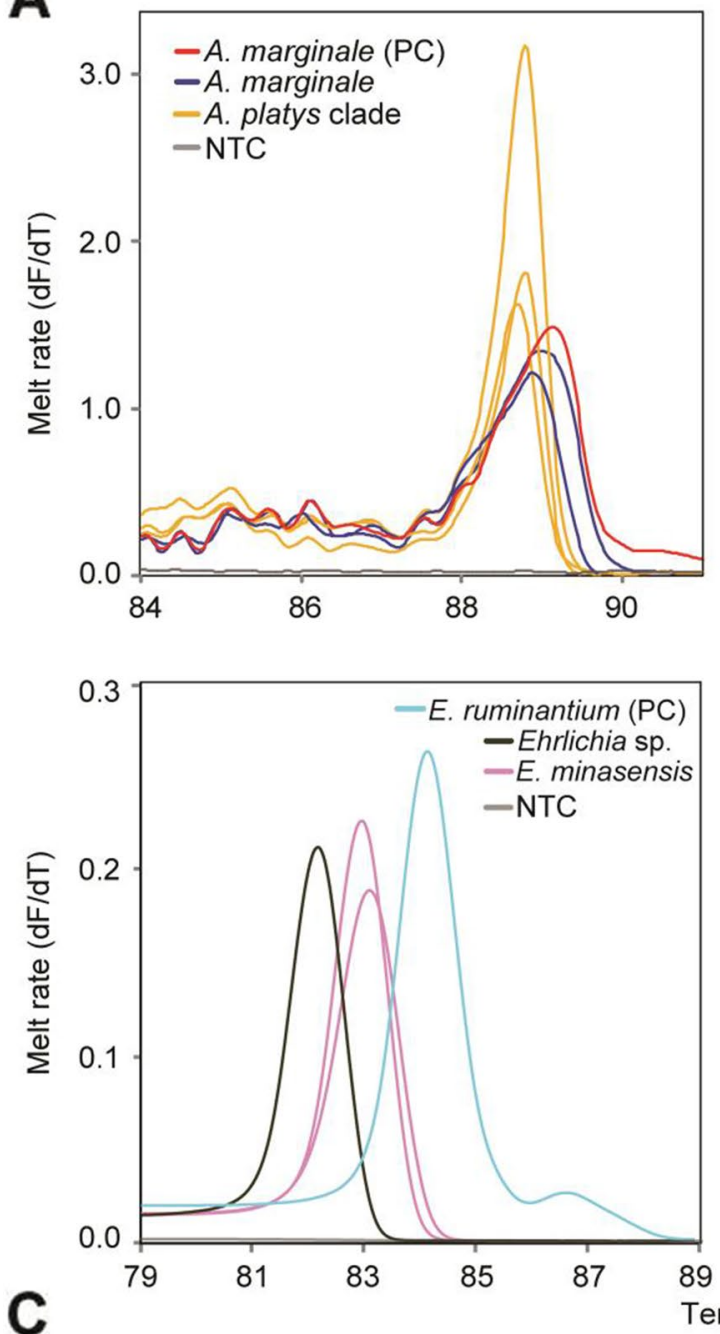

Temperature $^{\circ} \mathrm{C}$

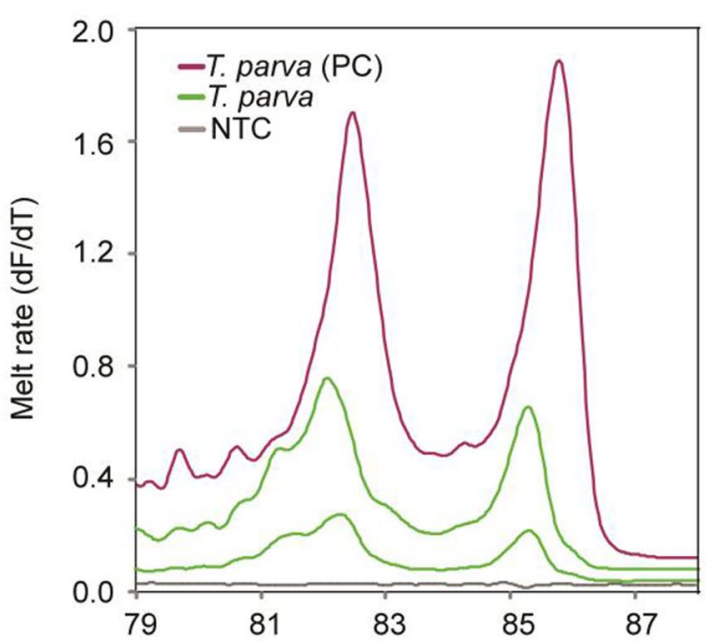

B
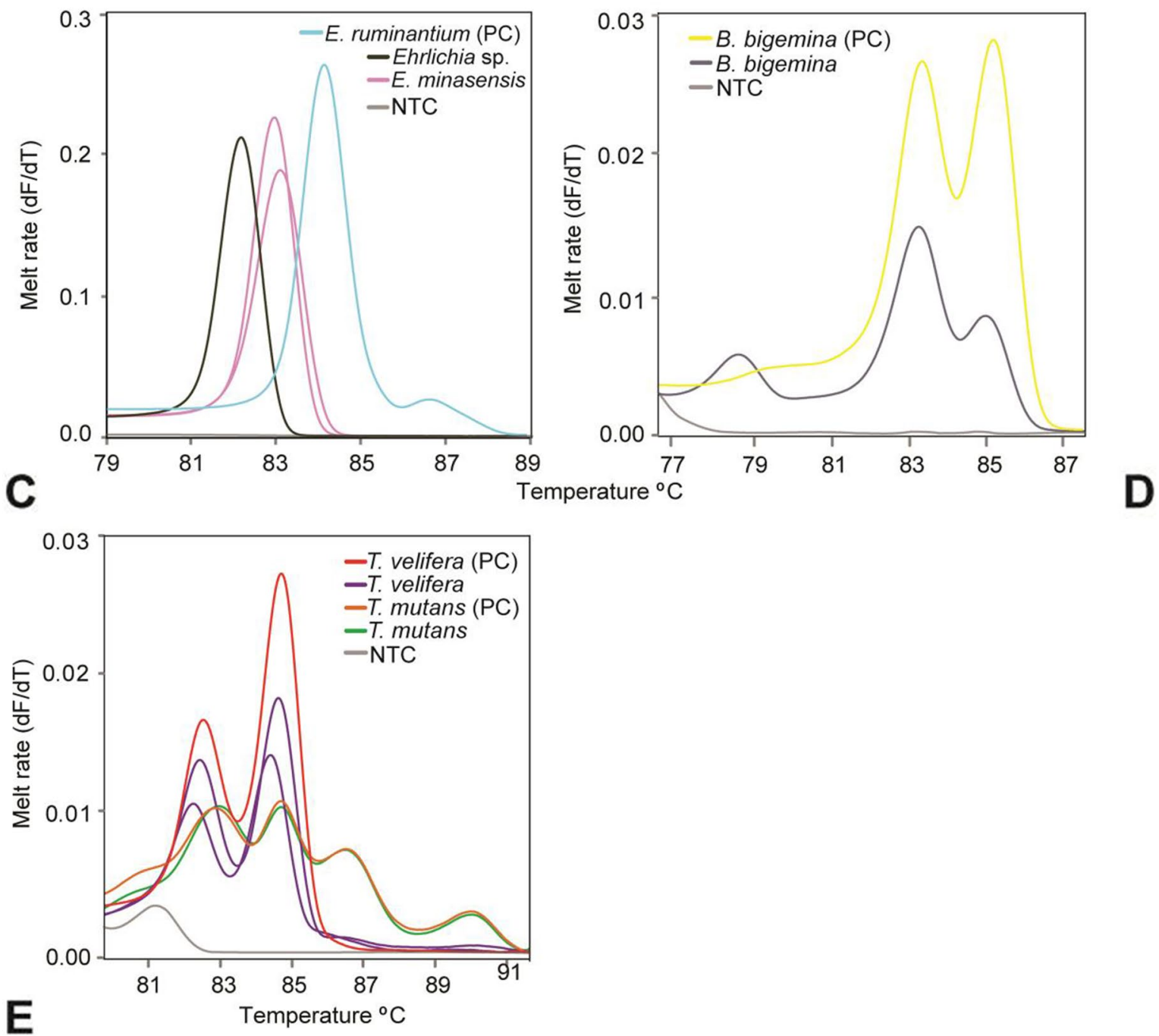

Fig. 1 PCR amplicon melt rate profiles of representative samples. A Anaplasma spp. 16S rRNA, B T. parva 18S rRNA, C Ehrlichia spp. 16S rRNA, D B. bigemina 18S rRNA, and E Theileria spp. $18 \mathrm{~S}$ rRNA. Positive controls are indicated by 'PC'. No template controls are shown by 'NTC'. Melt rates are represented as change in fluorescence with increasing temperature $(\mathrm{dF} / \mathrm{dT})$ 


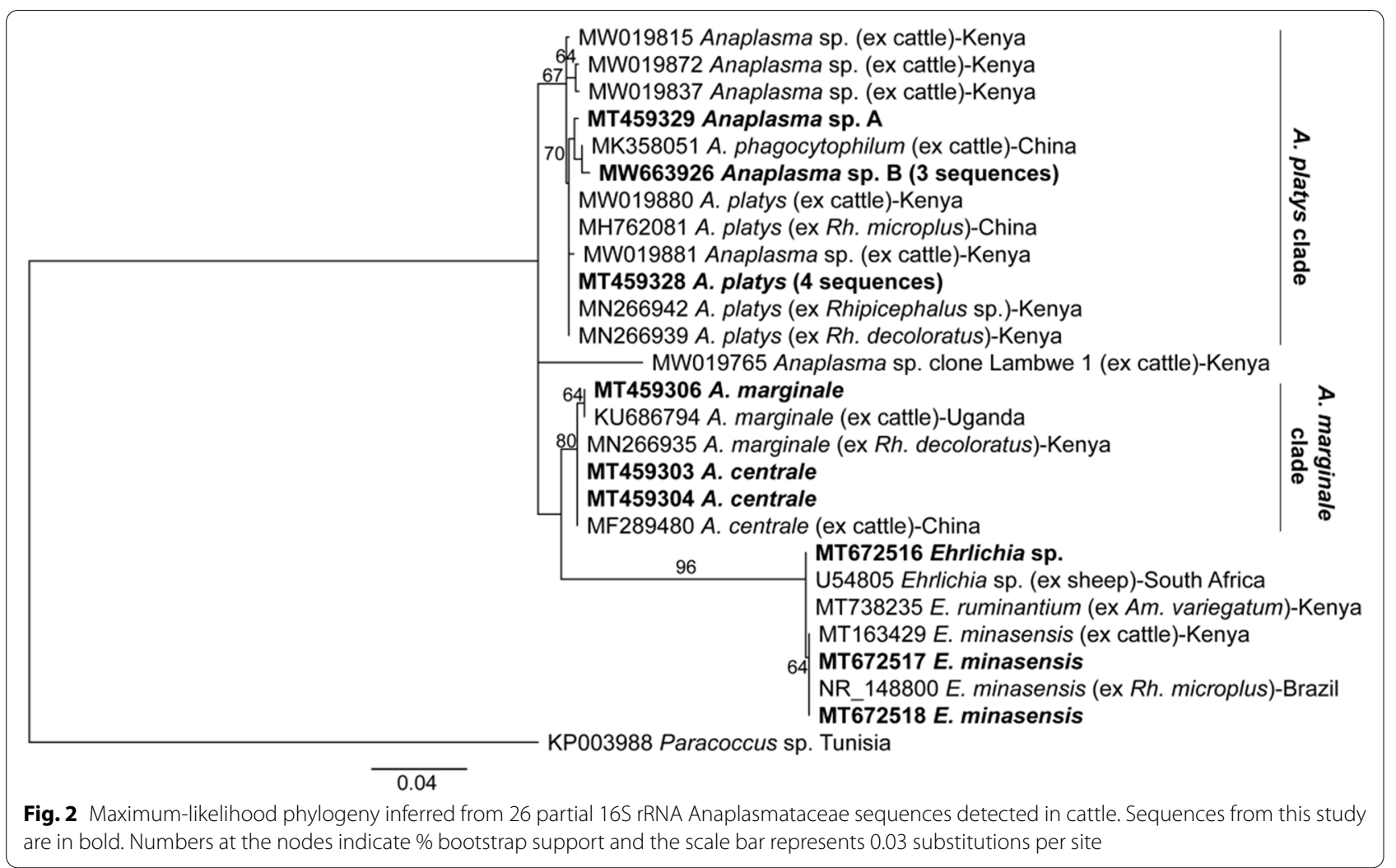

and tick presence were univariably associated with Ehrlichia spp. occurrence (Table 2).

Exotic breeds of cattle were significantly more likely to be infected with $A$. marginale (OR: $7.99,95 \% \mathrm{CI}$ : 3.04-22.02, $p<0.001$ ), and less likely to be infected with Theileria spp. (OR: 0.20, 95\% CI: 0.03-0.67, $p=0.023$ ), compared to local breeds. Cattle on which ticks were present were significantly more likely to be infected with Anaplasma spp. (OR: 2.18, 95\% CI: 1.32-3.69, $p=0.003$ ) and Ehrlichia spp. (OR: 2.79, 95\% CI: $1.22-$ 7.23, $p=0.022$ ), compared with those that had no ticks (Table 3). Cattle sampled at SHs were more likely to be positive for Anaplasma spp. (OR: 1.64, 95\% CI: 1.012.70, $p=0.048$ ) and $A$. marginale (OR: $3.84,95 \% \mathrm{CI}$ : 1.43-12.21, $p=0.012$ ) compared to those sampled at LMs. There was no significant difference with respect to sampling site on the other investigated TBPs (Table 3).

\section{Discussion}

In this study we detected the majority of TBPs of economic importance in livestock production in Kenya, including $T$. parva, B. bigemina and A. marginale. We also detected $E$. minasensis and $A$. platys, whose epidemiology and association with clinical disease in cattle in Kenya is still unclear. Phylogenetically, the detected TBPs were, as would be expected, closely related to strains reported previously in ticks and cattle in Kenya and Uganda, suggesting the possible movement of pathogens across borders within cattle harbouring the tick vectors. The natural resistance of local breeds to TBDs, the importance of tick control, and the potential for LMs and SHs to serve as surveillance points for TBPs are highlighted in our logistic regression analysis where exotic breeds, tick presence and sampling at SHs were associated with the occurrence of TBPs.

The overall prevalence of TBPs in this study was lower than what has been reported in previous studies in Kenya, including studies on two specific dairy farms in Kajiado and Machakos counties [3], calves from western Kenya [7], smallholder livestock systems from western Kenya highlands [5], Machakos County [30, 31], and at a wildlife-livestock interface in Lambwe Valley, western Kenya [33]. A probable explanation for this consistent difference between our study and previous ones is that some of the latter studies used serology, rather than PCR, for determining positivity to TBPs; serology is likely to generate higher prevalence than PCR since it measures historical exposure. Indeed, antibodies to T. parva were reported to persist in cattle for about 6 months after initial infection [49]. Higher prevalence of TBPs is also expected in cattle at wildlifelivestock interfaces due to spill over from wildlife, as 


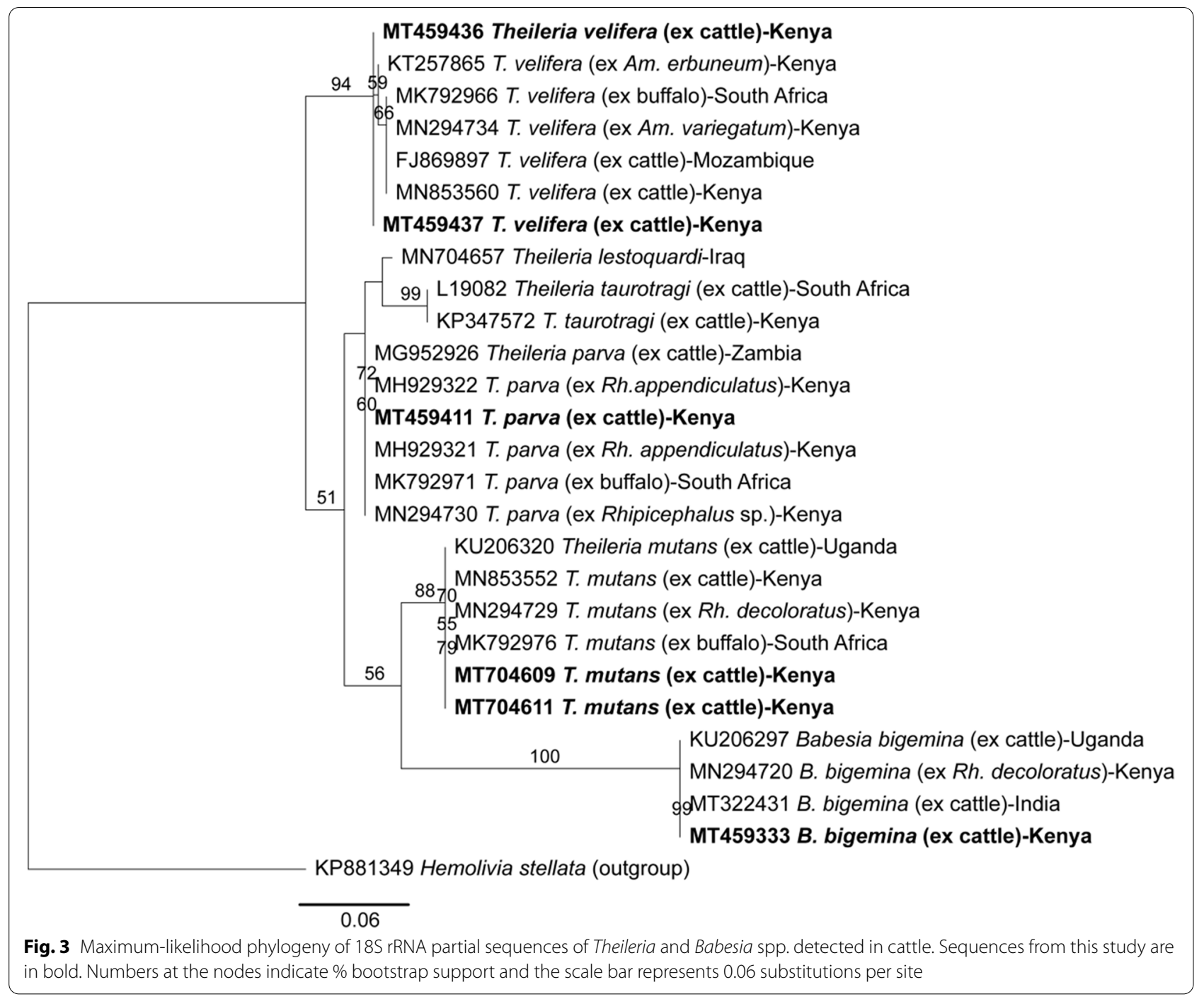

most of the TBPs have wildlife reservoir hosts such as buffalo [50].

In Uganda, a higher prevalence of TBPs was reported in livestock kept under pastoralism in the Karamoja region [48], while lower T. parva infection rates, comparable to those identified in our study, were reported in Tororo District of Eastern Uganda which borders western Kenya [51]. In smallholder livestock systems such as in western Kenya, there is variable immunity to East Coast fever and the mortality ranges from 3 to $20 \%$ [4]. However, the disease causes higher mortality rates of $40-80 \%$ in pastoral systems $[4,52]$. Poor tick control strategies and veterinary seeking behaviour have been attributed to the high incidence of TBPs in pastoralist communities [53]. The prevalence of TBPs identified in this study was also lower than that found in Ethiopia [54] and Cameroon [2], but comparable to that detected in China [55]. In this study, the low prevalence of $B$. bigemina and $A$. marginale, the major causes of bovine babesiosis and anaplasmosis, respectively, in Kenya, was consistent with other studies in the same region [5, 7]. Conversely, higher infection rates have been reported in other ecological zones, which are likely to be more suited to the survival of $R h$. decoloratus, the major vector of these pathogens in Kenya [3]. Ecology has been shown to influence parasite development in ticks, as higher temperatures are thought to retard or even eliminate the infective stages of $B$. bigemina in Rhipicephalus ticks [56]. The climate in our study region is equatorial, hot and humid with maximum temperatures ranging from $27^{\circ} \mathrm{C}$ to $32^{\circ} \mathrm{C}$ and an annual rainfall ranging between 1350 and $2400 \mathrm{~mm}$ [57]. Importantly, these temperatures are considerably higher than those around Nairobi and other highland regions [3] and may therefore hinder parasite development. The higher prevalence of Anaplasma spp. and A. marginale in cattle sampled at SHs, compared to those from LMs, suggests 
Table 1 Prevalence of Anaplasma, Babesia, Ehrlichia, and Theileria spp. detected in cattle from western Kenya

\begin{tabular}{lllll}
\hline & \multicolumn{4}{l}{ Percent prevalence by County } \\
\cline { 2 - 5 } Tick-borne pathogen & Busia & Bungoma & Kakamega & Total \\
& $(\mathbf{n}=\mathbf{5 1})$ & $\mathbf{( n = 9 9 )}$ & $\mathbf{( n = 2 7 2 )}$ & $\mathbf{( n = 4 2 2 )}$ \\
\hline Anaplasma spp. & $\mathbf{6 ( 1 1 . 8 )}$ & $\mathbf{1 7}(\mathbf{1 7 . 2 )}$ & $\mathbf{6 0 ( 2 2 . 1 )}$ & $\mathbf{8 3}(\mathbf{1 9 . 7 )}$ \\
A. centrale & $0(0)$ & $0(0)$ & $5(1.8)$ & $5(1.2)$ \\
A. marginale & $0(0)$ & $5(5.1)$ & $16(5.9)$ & $21(5.0)$ \\
A. platys clade & $6(11.8)$ & $12(12.1)$ & $39(14.3)$ & $57(13.5)$ \\
Babesia spp. & $\mathbf{0 ( 0 )}$ & $\mathbf{0 ( 0 )}$ & $\mathbf{1}(\mathbf{0 . 4})$ & $\mathbf{1}(\mathbf{0 . 2})$ \\
B. bigemina & $0(0)$ & $0(0)$ & $1(0.4)$ & $1(0.2)$ \\
Ehrlichia spp. & $\mathbf{6 ( 1 1 . 8 )}$ & $\mathbf{5 ( 5 . 1 )}$ & $\mathbf{1 7}(\mathbf{6 . 3})$ & $\mathbf{2 8}(6.6)$ \\
E. minasensis & $0(0)$ & $1(1.0)$ & $1(0.4)$ & $2(0.5)$ \\
Ehrlichia sp. & $\mathbf{6 ( 1 1 . 8 )}$ & $4(4.0)$ & $16(5.9)$ & $26(6.2)$ \\
Theileria spp. & $\mathbf{5 ( 9 . 8 )}$ & $\mathbf{1 0 ( 1 0 . 1 )}$ & $\mathbf{3 7 ( 1 3 . 6 )}$ & $\mathbf{5 2}(\mathbf{1 2 . 3 )}$ \\
T. mutans & $2(3.9)$ & $4(4.0)$ & $7(2.6)$ & $13(3.1)$ \\
T. parva & $0(0)$ & $0(0)$ & $7(2.6)$ & $7(1.7)$ \\
T. taurotragi & $0(0)$ & $0(0)$ & $1(0.4)$ & $1(0.2)$ \\
T. velifera & $3(5.9)$ & $6(6.1)$ & $22(8.1)$ & $31(7.3)$ \\
\hline
\end{tabular}

that cattle owners/traders may seek to dispose of sick animals, presumably from TBP infection, via slaughter rather than trading them at LMs. Concomitantly, butchers at these SHs are likely to benefit from buying sick animals at cheaper prices. However, in this study, the body condition score, which is one of the most important variables considered by buyers and sellers of cattle at these $\mathrm{LMs} / \mathrm{SHs}$, was not associated with the occurrence of TBPs.

There was a higher prevalence of the mildly pathogenic non-transforming Theileria spp. compared to T. parva infections, similar to what has previously been reported in Kenya [7], Uganda [48], and Ethiopia [54]. Non-transforming Theileria spp. do not induce proliferation of infected lymphocytes and therefore cause only a mild disease in cattle [58]. These benign species have been shown to play an important role in reducing morbidity and mortality due to the pathogenic T. parva in indigenous co-infected cattle [59]. We also report the occurrence of dual infections in some of the positive samples, which is expected as we detected multiple TBP infections in individual ticks collected from the same cattle sampled in this study [26]. Co-infection with both benign and pathogenic species is desirable as the benign Theileria spp. are thought to reduce severity of pathogenic species infection via a superinfection mechanism [59]. Correspondingly, these apparently healthy animals at LMs are epidemiologically important as they facilitate the dissemination of TBPs to new areas when they are traded. On the other hand, when both co-infecting species are pathogenic the host's ability to mount an effective immune response may be impeded, resulting in severe clinical disease [10, 60, 61]. Indeed, the mildly pathogenic Theileria spp. have dominated co-infections in previous studies $[3,7,33,62]$.

In this study we detected several A. platys-like organisms, which are principally canine pathogens causing cyclic thrombocytopenia in dogs. However, they have recently been found to also infect humans, causing clinical disease $[14,16,63]$. Therefore, SH and LM workers are at risk of infection by this organism through infective tick bites. There has also been widespread detection of $A$. platys in apparently healthy cattle [33, 55, 64]. We speculate that the vector, Rhipicephalus sanguineus, may be feeding on both dogs and cattle in regions where they co-exist, such as in our study region where free-roaming dogs have been observed to frequent poorly managed SHs [65]. As a result, this dog-tick-cattle cycle can establish a transmission cycle of $A$. platys that can also potentially involve humans. We also report the occurrence of the recently described E. minasensis [66] in cattle blood, which has been shown to cause bovine ehrlichiosis in Brazil [67]. In our study, the positive cattle did not show any apparent clinical disease. In Kenya, E. minasensis has also been recently reported in apparently healthy dairy cows, highlighting the need for more studies to determine its clinical relevance in the country [25].

We found that exotic cattle breeds were significantly more likely to be infected with A. marginale. Generally, Zebu and indigenous breeds have been reported to be less susceptible to TBPs than exotic breeds, due to their innate resistance and constant exposure to TBP infected tick bites, which regularly primes their immune system [68]. This infection pressure ensures that new-born calves are exposed to the pathogen early before their maternal acquired immunity wanes [30]. Comparatively, the immune system of exotic breeds will be naïve, hence they are more susceptible to the adverse effects of TBPs. Conversely, exotic breeds and cross-bred cattle appeared to be less susceptible to Theileria spp. infection compared to local breeds. However, this could be due to the low number of infected exotic cattle, compared to local cattle, included in the regression analysis.

Tick presence was significantly associated with the occurrence of Anaplasma spp. and Ehrlichia spp., which is expected since ticks are the vectors driving the transmission, and their epidemiology therefore closely mirrors that of TBPs $[10,69]$. The stability of endemicity in a given region depends on the suitability of the ecology for the survival of ticks in that area [68]. In our previous study on the same site [26], we collected diverse tick species from the same animals; therefore, this association is most likely to be pronounced for Anaplasma spp. and 

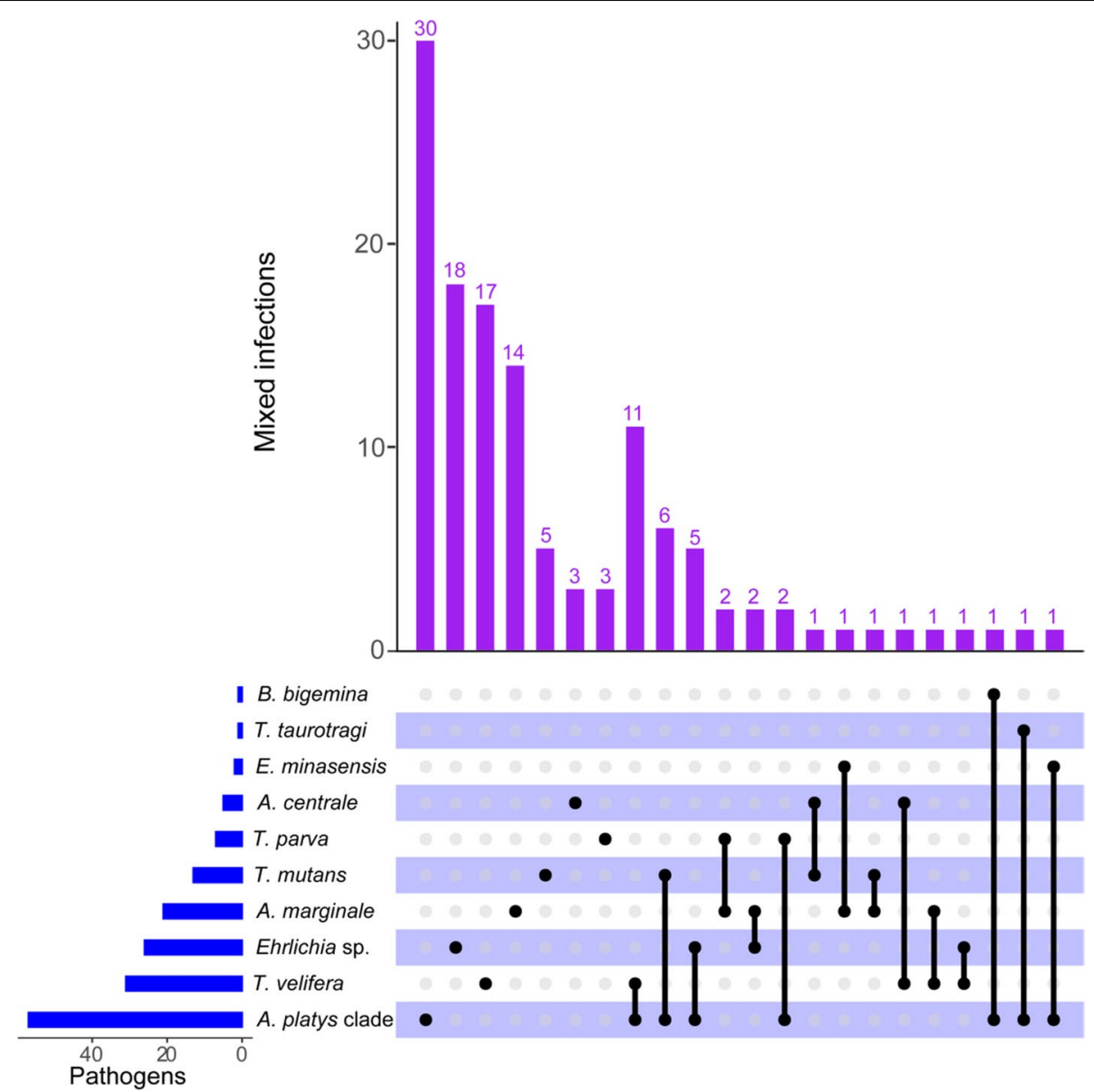

Fig. 4 UpSetR plot showing the frequency of dual infections of tick-borne pathogens detected in cattle from western Kenya. The blue bar plot on the left shows the total number of pathogens of each species detected while the matrix shows single (black dots) and dual infections (black dots connected by black lines) whose frequency is depicted by the purple bar plot

Ehrlichia spp. because they are transmitted by several tick species and even mechanically, unlike T. mutans and T. velifera that are restricted to Amblyomma spp. None of the other risk factors that we investigated, such as animal sex and age, were significant predictors of TBP infection.

We did not detect E. ruminantium, Rickettsia spp., or any viruses such as CCHF. Ehrlichia ruminantium, the cause of heartwater in ruminants, is found mostly in endothelial cells causing vasculitis and has very few stages circulating in the blood system during chronic illness. This means that, given its low presence in peripheral blood, it is less likely to be picked up by ticks and other mechanical vectors, hence the low transmissibility $[9,70]$. Recent studies have not detected this pathogen in cattle [33], and low detection of Ehrlichia spp. in ticks has been reported in previous studies in Kenya [26, 71, 72]. On the other hand, E. ruminantium, B. bigemina and T. parva all cause severe disease, hence cattle infected with these pathogens may not be presented for sale or slaughter in cases of acute disease leading to deaths on the farm. However, our experience at these LMs and SHs has shown us that a variety of cattle are brought for potential trading or slaughter, including some in very poor condition. Ehrlichia ruminantium has also been implicated as a potential cause of undifferentiated camel diseases in northern Kenya [73], and has been associated with ticks of tortoises [72] and even with humans [74].

The absence of Rickettsia spp., especially $R$. africae, is surprising because a similar study detected a high prevalence of the pathogen in Am. variegatum ticks [46], as we previously did in Am. variegatum ticks removed from the same animals whose blood samples are analysed here [26]. However, a similar recent study in Kenya also did not report any Rickettsia spp. from cattle [33]. Given that Am. variegatum ticks are the reservoirs of $R$. africae, these findings may indicate that the ticks may not be efficient vectors of the pathogen and that cattle develop low, transient rickettsaemia and only serve to harbour 
Table 2 Descriptive statistics and univariable logistic regression analysis of predictor variables associated with tick-borne pathogen occurrence in cattle

\begin{tabular}{|c|c|c|c|c|}
\hline Variables & Categories & Prevalence (\%) & Odds ratio $(95 \% \mathrm{Cl})$ & $p$-value \\
\hline \multicolumn{5}{|c|}{ Anaplasma spp. } \\
\hline \multirow[t]{3}{*}{ Breed } & Exotic & $16 / 62(25.8)$ & $1.64(0.84-3.09)$ & 0.132 \\
\hline & Cross & $17 / 74(23.0)$ & $1.41(0.74-2.58)$ & 0.281 \\
\hline & Local & $50 / 286(17.5)$ & Reference & Overall $=0.251$ \\
\hline \multirow[t]{2}{*}{ Sex } & Male & $42 / 207(20.3)$ & $1.08(0.67-1.75)$ & 0.753 \\
\hline & Female & $41 / 215(19.1)$ & Reference & \\
\hline \multirow[t]{2}{*}{ Age } & $\geq 12$ months & $76 / 369$ (20.6) & $1.70(0.79-4.27)$ & 0.187 \\
\hline & $<12$ months & $7 / 53(13.2)$ & Reference & \\
\hline \multirow[t]{2}{*}{$\mathrm{BCS}$} & $3-5$ & 27/133 (20.3) & $1.06(0.63-1.76)$ & 0.825 \\
\hline & $1-2.5$ & $56 / 289(19.4)$ & Reference & \\
\hline \multirow[t]{2}{*}{ Ticks } & Present & $56 / 225(24.9)$ & $2.09(1.27-3.50)$ & $0.004 * *$ \\
\hline & Absent & 27/197 (13.7) & Reference & \\
\hline \multirow[t]{2}{*}{ Sampling site } & $\mathrm{SH}$ & $47 / 203(23.2)$ & $1.53(0.95-2.50)$ & 0.083 \\
\hline & LM & $36 / 219(16.4)$ & Reference & \\
\hline \multicolumn{5}{|l|}{ Ehrlichia spp. } \\
\hline \multirow[t]{3}{*}{ Breed } & Exotic & 10/62 (16.1) & $2.21(0.87-5.18)$ & 0.079 \\
\hline & Cross & $3 / 74(4.1)$ & $0.41(0.06-1.48)$ & 0.244 \\
\hline & Local & $15 / 286(5.2)$ & Reference & Overall $=0.063$ \\
\hline \multirow[t]{2}{*}{ Sex } & Male & $15 / 207(7.2)$ & $1.21(0.56-2.66)$ & 0.621 \\
\hline & Female & $13 / 215(6.0)$ & Reference & \\
\hline \multirow[t]{2}{*}{ Age } & $\geq 12$ months & $25 / 369(6.8)$ & $1.21(0.41-5.22)$ & 0.756 \\
\hline & $<12$ months & $3 / 53(5.7)$ & Reference & \\
\hline \multirow[t]{2}{*}{ BCS } & $3-5$ & $7 / 133(5.3)$ & $0.71(0.27-1.64)$ & 0.433 \\
\hline & $1-2.5$ & $21 / 289(7.3)$ & Reference & \\
\hline \multirow[t]{2}{*}{ Ticks } & Present & $21 / 225(9.3)$ & $2.79(1.22-7.23)$ & $0.015^{*}$ \\
\hline & Absent & 7/197 (3.6) & Reference & \\
\hline \multirow[t]{2}{*}{ Sampling site } & $\mathrm{SH}$ & $13 / 203(6.4)$ & $0.93(0.43-2.01)$ & 0.854 \\
\hline & LM & $15 / 219(6.8)$ & Reference & \\
\hline \multicolumn{5}{|l|}{ Theileria spp. } \\
\hline \multirow[t]{3}{*}{ Breed } & Exotic & $2 / 62(3.2)$ & $0.20(0.03-0.67)$ & $0.029 *$ \\
\hline & Cross & $9 / 74(12.2)$ & $0.83(0.36-1.72)$ & 0.630 \\
\hline & Local & $41 / 286(14.3)$ & Reference & Overall $=0.023^{*}$ \\
\hline \multirow[t]{2}{*}{ Sex } & Male & 25/207 (12.1) & $0.96(0.53-1.71)$ & 0.881 \\
\hline & Female & $27 / 215$ (12.6) & Reference & \\
\hline \multirow[t]{2}{*}{ Age } & $\geq 12$ months & $44 / 369(11.9)$ & $0.76(0.35-1.84)$ & 0.522 \\
\hline & $<12$ months & 8/53 (15.1) & Reference & \\
\hline \multirow[t]{2}{*}{ BCS } & $3-5$ & 21/133 (15.8) & $1.56(0.85-2.82)$ & 0.149 \\
\hline & $1-2.5$ & $31 / 289(10.7)$ & Reference & \\
\hline \multirow[t]{2}{*}{ Ticks } & Present & $28 / 225(12.4)$ & $1.02(0.57-1.85)$ & 0.935 \\
\hline & Absent & 24/197 (12.2) & Reference & \\
\hline \multirow[t]{2}{*}{ Sampling site } & $\mathrm{SH}$ & $31 / 203(15.3)$ & $1.70(0.95-3.10)$ & 0.076 \\
\hline & LM & $21 / 219(9.6)$ & Reference & \\
\hline \multicolumn{5}{|l|}{ A. marginale } \\
\hline Breed & Exotic & $11 / 62(17.7)$ & $7.50(2.90-20.24)$ & $<0.001$ \\
\hline & Cross & $2 / 74(2.7)$ & $0.96(0.14-3.95)$ & 0.965 \\
\hline & Local & 8/286 (2.8) & Reference & Overall $<0.001^{* * *}$ \\
\hline Sex & Male & $11 / 207(5.3)$ & $1.15(0.47-2.82)$ & 0.754 \\
\hline & Female & $10 / 215$ & Reference & \\
\hline
\end{tabular}


Table 2 (continued)

\begin{tabular}{|c|c|c|c|c|}
\hline Variables & Categories & Prevalence (\%) & Odds ratio $(95 \% \mathrm{Cl})$ & $p$-value \\
\hline \multirow[t]{2}{*}{ BCS } & $3-5$ & 5/133 (3.8) & $0.67(0.21-1.74)$ & 0.424 \\
\hline & $1-2.5$ & $16 / 289(5.5)$ & Reference & \\
\hline \multirow[t]{2}{*}{ Ticks } & Present & $14 / 225(6.2)$ & $1.80(0.73-4.84)$ & 0.203 \\
\hline & Absent & 7/197 (3.6) & Reference & \\
\hline \multirow[t]{2}{*}{ Sampling site } & $\mathrm{SH}$ & 16/203 (7.9) & $3.66(1.40-11.37)$ & $0.007^{* *}$ \\
\hline & LM & $5 / 219(2.3)$ & Reference & \\
\hline
\end{tabular}

Significant codes: ${ }^{*}=<0.05 ;{ }^{* *}=<0.01 ;{ }^{* * *}=<0.001 ; \mathrm{LM}=$ livestock market; $\mathrm{SH}=$ slaughterhouse

the tick (Am. variegatum) and not the pathogen in the epidemiology of rickettsioses. This is supported by a previous study in Argentina where all of the cattle followed up for 18 months did not have measurable rickettsaemia, but $90 \%$ of them were seropositive for Rickettsia parkeri a related spotted fever group Rickettsia. Additionally, 20\% of the ticks removed from these cattle were positive for $R$. parkeri DNA [75]. Therefore, serological surveys may provide more information when studying the exposure of cattle to $R$. africae, compared to molecular methods that target the pathogen's DNA.

The use of archived samples may have decreased the ability to detect TBPs, especially viruses, in the blood samples after several freeze-thaw cycles. Outside

Table 3 Logistic regression analyses results for the occurrence of tick-borne pathogens in cattle and associated predictor variables

\begin{tabular}{|c|c|c|c|}
\hline Variables & Categories & Odds ratio $(95 \% \mathrm{Cl})$ & $p$-value \\
\hline \multicolumn{4}{|c|}{ Anaplasma spp. } \\
\hline \multirow[t]{2}{*}{ Ticks } & Present & $2.18(1.32-3.69)$ & 0.003 \\
\hline & Absent & Reference & \\
\hline \multirow[t]{2}{*}{ Sampling site } & $\mathrm{SH}$ & $1.64(1.01-2.70)$ & 0.048 \\
\hline & LM & Reference & \\
\hline \multicolumn{4}{|l|}{ Ehrlichia spp. } \\
\hline \multirow[t]{2}{*}{ Ticks } & Present & $2.79(1.22-7.23)$ & 0.022 \\
\hline & Absent & Reference & \\
\hline \multicolumn{4}{|l|}{ Theileria spp. } \\
\hline \multirow[t]{3}{*}{ Breed } & Exotic & $0.20(0.03-0.67)$ & 0.029 \\
\hline & Cross & $0.83(0.36-1.72)$ & 0.630 \\
\hline & Local & Reference & Overall $=\mathbf{0 . 0 2 3}$ \\
\hline \multicolumn{4}{|l|}{ A. marginale } \\
\hline \multirow[t]{3}{*}{ Breed } & Exotic & 7.99 (3.04-22.02) & $<0.001$ \\
\hline & Cross & $1.16(0.17-4.84)$ & 0.855 \\
\hline & Local & Reference & Overall $=<0.001$ \\
\hline \multirow[t]{2}{*}{ Sampling site } & $\mathrm{SH}$ & $3.84(1.43-12.21)$ & 0.012 \\
\hline & LM & Reference & \\
\hline
\end{tabular}

Significant $p$-values are shown in bold italic; $S H$ slaughterhouse, $L M$ livestock market outbreak phases, the viraemia caused by CCHF and Rift Valley fever in reservoir hosts such as cattle may be lower than the PCR detectable limits [76]; hence the combined use of PCR and serology may give a clearer picture of their occurrence. This challenge is also reflected in the low infection rates of these arboviruses in their major vectors, such as ticks and mosquitoes collected from the same sampling sites [26, 77]. Moreover, arboviruses, such as dengue and chikungunya, have limited enzootic cycles and cattle do not seem to be play a key role in their maintenance $[78,79]$. To counter the occurrence of false negatives, internal PCR controls that amplify host messenger RNA can be developed and used in future viral analysis. The sample selection also did not permit equal/proportional representation of the sampling sites and other variables in the final batch of selected samples, and subsequently limited the statistical analyses that could be performed. Future studies could employ a matched case-control study design to ensure sufficient numbers of positive cases are included.

While in some cases, samples collected from sentinel sites such as LMs and SHs may not substantially reflect the prevalence of TBPs in the specific localities investigated, our sampling site selection was done purposively to include both small and large sites, which received cattle from the vicinity (within county) and from other neighbouring counties, respectively [80]. Moreover, in a related study in the same region, most of the cattle (99.7\%) that were brought to SHs were sourced from within the county [81]. Central point sampling at sites such as at LMs/SHs has also been found to be representative of the actual prevalence of other vector-borne diseases affecting cattle, especially in epidemic foci. Furthermore, central point sampling is more cost-effective and logistically convenient [82].

The use of primers targeting the 16S rRNA region of tick-borne bacteria, even those amplifying long fragments of up to 1000 base pairs, may also have limited our ability to precisely resolve some of the TBPs 
especially Anaplasma spp. Despite these limitations, this study reveals the occurrence (single and dual infections) and diversity of TBPs, and some of the important factors influencing their occurrence, in cattle in western Kenya.

\section{Conclusions}

We detected TBPs of economic and potential zoonotic importance in cattle at LMs and SHs. These findings underline the importance of these sentinel sites in studying the transmission dynamics of cattle TBPs and tickborne zoonotic pathogens as apparently healthy cattle are traded at these LMs and SHs. The veterinary or zoonotic importance of the recently described E. minasensis needs further investigation in the local context, while in future the use of other genetic markers such as the heat shock protein (groEL) and major surface protein $4(m s p 4)$ genes, in combination with the $16 \mathrm{~S}$ rRNA marker, may improve the resolution of $A$. platys-like pathogens detected. With increasing reports of the occurrence of this bacterial species in humans elsewhere it is also important to assess $A$. platys presence and its association with clinical cases in humans in Kenya. Furthermore, competence studies on the transmission of $R$. africae by Am. variegatum ticks in the local context are required to explain its absence in cattle blood samples. Livestock markets are an important source of subsistence in the livestock production sector, but they can also pose a risk of translocation of apparently healthy but infected cattle to other areas. Given this information, surveillance for TBPs at these sites and the importance of tick control should be emphasized, together with the regulation of cattle movement and trade at these points of livestock concentration.

\section{Methods}

\section{Study site and livestock sampling}

The study was based in western Kenya, on the border with Uganda. The study sites, which included the counties of Busia, Bungoma and Kakamega, lie in the East African Lake Victoria basin, where there is an abundance of livestock raised in smallholder production systems.

This study was part of a larger study to develop an integrated surveillance system for zoonotic diseases in western Kenya using hospitals, LMs and SHs as sentinel sites [80]. Briefly, a sampling framework of all the LMs and $\mathrm{SHs}$ in the three counties was established. From this, four LMs and neighbouring SHs in each county were selected for sampling; the selection was based on the animal throughput at each site and their accessibility from Busia town where our field laboratory was located. Each LM and neighbouring $\mathrm{SH}$ were visited once every four weeks over a two-year period. During each visit, up to 10 animals were sampled at each site. At LMs, the 10 sampled animals, which included cattle and small ruminants, were randomly selected. At the SHs, all the animals brought to slaughter (if $\leq 10$ ), or a sub-set of these (if $>10$ ), were sampled, and these included cattle, small ruminants, and pigs.

A clinical examination was performed on each sampled animal, and blood samples were collected from the jugular vein into $10 \mathrm{ml}$ plain, heparinized, and EDTA tubes (BD Vacutainer ${ }^{\circledR}$ ) using an 18-gauge rubber-capped needle. The presence of ticks on the animal was also noted. Blood samples were transported to the International Livestock Research Institute (ILRI) field lab in Busia in a cooler box on ice packs, and later shipped on dry ice to the ILRI Nairobi laboratory where they were stored at $-80^{\circ} \mathrm{C}$.

In total, 1977 and 1509 animals were sampled at the LMs and SHs, respectively; of these, 1293 and 885 were cattle [80]. For this study, we included blood samples and associated meta-data of 422 cattle which were sampled in seven LMs $(n=219)$ and seven SHs $(n=203)$ in the three counties (Fig. 5). Selection criteria for these 422 samples analysed in this study included: (i) cattle sampled between May 2017 and January 2019, for which TBPs (viral/bacteria/protozoa) data were available [26], (ii) availability of complete meta-data, and (iii) blood volumes adequate for the envisaged analyses. Furthermore, because CCHF virus positive ticks were detected in Kakamega [26], samples from Kakamega County were prioritized. Selected samples were thawed, aliquoted and transported on ice to the Martin Lüscher Emerging Infectious Disease (ML-EID) laboratory at the International Centre of Insect Physiology and Ecology (icipe) where subsequent analyses were performed.

\section{Nucleic acid extraction}

We extracted both DNA and RNA from blood using the TRIzol $^{\mathrm{TM}}$ reagent standard protocol (Thermofisher, USA). Dengue serotype 2 and Sindbis virus cultured on Vero cell lines in a previous study were included in each RNA extraction run [83]. After nucleic acid extraction, $5 \mu \mathrm{l}$ of the total RNA was subjected to cDNA synthesis using a High Capacity cDNA Reverse Transcription (RT) kit (Life Technologies, USA). The ' $10 \mu \mathrm{l}$ ' reaction mixtures contained 1X RT buffer, $4 \mathrm{mM}$ dNTPs, $600 \mu \mathrm{M}$ random hexamers [84], 2.5 $\mathrm{U} / \mu \mathrm{l}$ reverse transcriptase enzyme, and $1 \mathrm{U} / \mu \mathrm{l}$ RNAse inhibitor.

\section{Molecular detection of arboviral, bacterial, and protozoan pathogens \\ Detection of arboviruses}

An established multiplex PCR coupled with high-resolution melting (HRM) analysis was used to screen blood samples for arboviruses [83]. The reaction mixture 


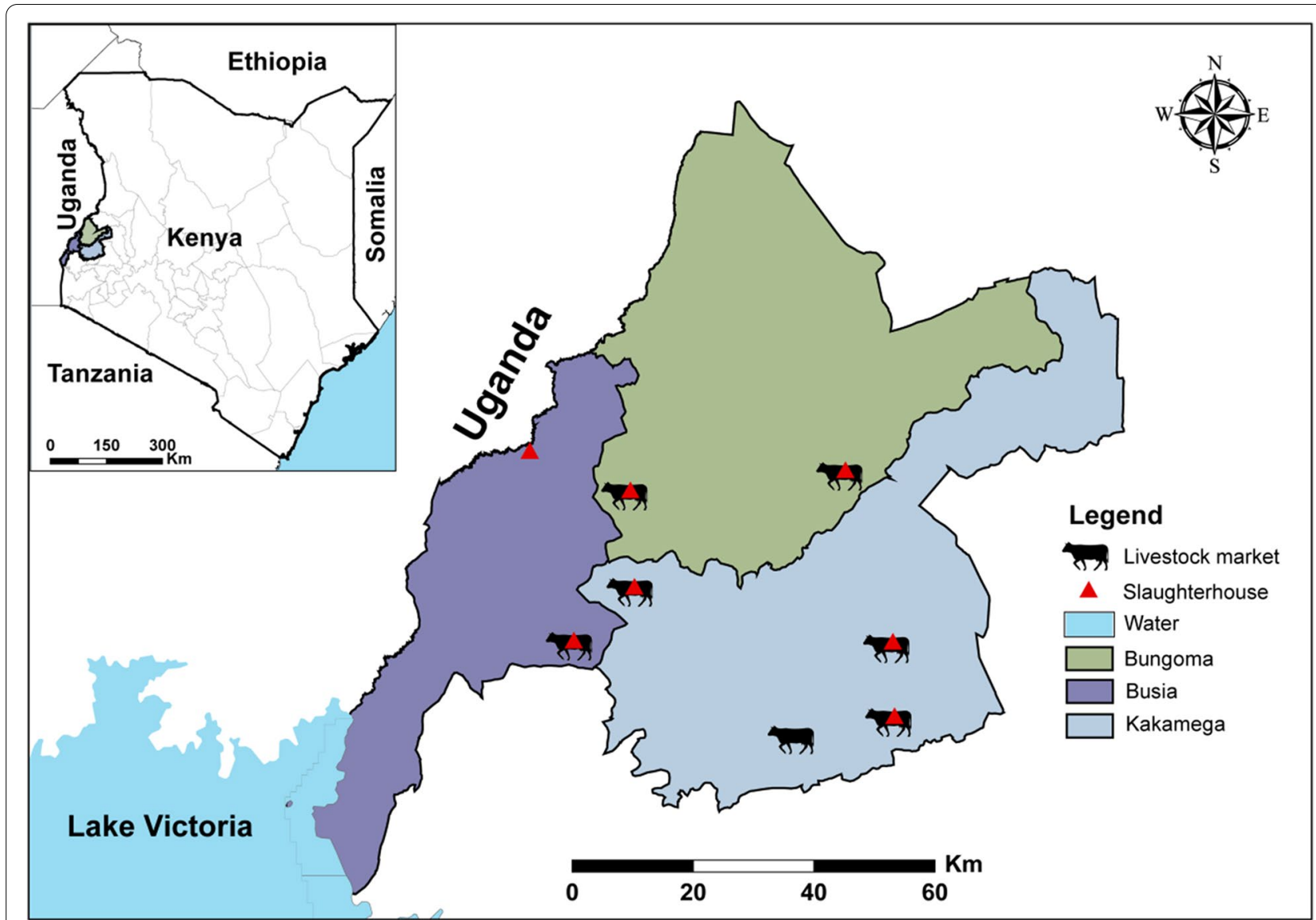

Fig. 5 Map of western Kenya showing the three neighbouring counties included in this study. Slaughterhouses and livestock markets from which blood samples used in this study were collected from cattle are shown

contained $1 \mu \mathrm{l}$ of cDNA template, $5 \mu \mathrm{l}$ of $2 \mathrm{x}$ MyTaq HS Mix (Bioline, UK), $1 \mu \mathrm{l}$ of $50 \mu \mathrm{M}$ SYTO-9 (Life Technologies, USA) and degenerate primer mix (Table 4). The amplicons were subjected to HRM following amplification with previously described thermal cycling conditions [83]. End-reaction melting profiles were visually inspected to identify samples with melt peaks representing specific amplification.

\section{Detection of bacterial and protozoan pathogens}

Using a combination of PCR-HRM and conventional PCR, previously developed genus-specific methods and primers were used to detect Rickettsia, Anaplasma, and Ehrlichia 16S rRNA, and Theileria and Babesia 18S rRNA gene sequences. Ten-microliter reactions that consisted of $2 \mu \mathrm{l}$ template, $2 \mu \mathrm{l} 5 \mathrm{X}$ HOT FIREPol ${ }^{\circledR}$ EvaGreen HRM Mix (Solis BioDyne, Estonia) and $0.5 \mu \mathrm{M}$ of each primer were constituted for the PCR-HRM. Positive controls of Anaplasma, Rickettsia, Theileria, and Babesia spp. previously detected in clinical samples banked in icipe's ML-EID lab were included in the runs. Second stage amplification of positive samples utilised different primers to generate larger PCR products where possible (Table 4) for sequencing and phylogenetic inference purposes.

Positive Ehrlichia spp. and Anaplasma spp. samples were further amplified with a conventional semi-nested PCR using the following touchdown PCR cycling conditions: for primary amplification, a hot-start activation step of $95^{\circ} \mathrm{C}$ of $15 \mathrm{~min}$ was followed by 1 cycle at an annealing temperature (Ta) of $63^{\circ} \mathrm{C}$ for $30 \mathrm{~s}, 2$ cycles at a Ta of $62^{\circ} \mathrm{C}$ for $30 \mathrm{~s}, 2$ cycles at a Ta of $61^{\circ} \mathrm{C}$ for $30 \mathrm{~s}$, and 35 cycles at a Ta of $60^{\circ} \mathrm{C}$ for $30 \mathrm{~s}$. Each of these annealing steps was preceded by a denaturation step of $95^{\circ} \mathrm{C}$ for $20 \mathrm{~s}$, and followed by primer extension at $72^{\circ} \mathrm{C}$ for $80 \mathrm{~s}$, with the final extension being conducted at $72^{\circ} \mathrm{C}$ for $10 \mathrm{~min}$. The secondary amplification utilized $2 \mu \mathrm{l} \mathrm{PCR}$ products from the primary reactions in $20 \mu \mathrm{l}$ reactions. The cycling profile consisted of $95^{\circ} \mathrm{C}$ for $15 \mathrm{~min}$; 3 cycles of $95^{\circ} \mathrm{C}$ for $20 \mathrm{~s}, 61^{\circ} \mathrm{C}$ for $30 \mathrm{~s}$, and $72^{\circ} \mathrm{C}$ for $90 \mathrm{~s} ; 37$ cycles of $95^{\circ} \mathrm{C}$ for $20 \mathrm{~s}, 60^{\circ} \mathrm{C}$ for $30 \mathrm{~s}$, and $72^{\circ} \mathrm{C}$ for $80 \mathrm{~s}$, and a final extension at $72{ }^{\circ} \mathrm{C}$ for $10 \mathrm{~min}$. All amplicons were 
Table 4 Primers that were used for the detection of arboviruses, tick-borne bacteria and protozoa

\begin{tabular}{|c|c|c|c|c|}
\hline Target gene & Primer name & Primer sequence $\left(5^{\prime}-3^{\prime}\right)$ & $\begin{array}{l}\text { Product size } \\
\text { (bp) }\end{array}$ & References \\
\hline \multirow[t]{3}{*}{ Phlebovirus NP (S-segment) } & Phlebo JV3a F & AGTTTGCTTATCAAGGGTTTGATGC & 150 & {$[83]$} \\
\hline & Phlebo JV3b F & GAGTTTGCTTATCAAGGGTTTGACC & & \\
\hline & Phlebo JV3 R & CCGGCAAAGCTGGGGTGCAT & & \\
\hline \multirow[t]{6}{*}{ Nairovirus RdRp (L-segment) } & Nairo L 1a F & TCTCAAAGATATCAATCCCCCCITTACCC & 150 & [83] \\
\hline & Nairo L 1b F & TCTCAAAGACATCAATCCCCCTTWTCCC & & \\
\hline & Nairo L 1a R & CTATRCTGTGRTAGAAGCAGTTCCCATC & & \\
\hline & Nairo L $1 b R$ & GCAATACTATGATAAAAACAATTMCCATCAC & & \\
\hline & Nairo L 1CR & CAATGCTGTGRTARAARCAGTTGCCATC & & \\
\hline & Nairo L 1d R & GCAATGCTATGGTAGAAACAGTTTCCATC & & \\
\hline \multirow[t]{2}{*}{ Alphavirus NS4 } & Vir $2052 \mathrm{~F}$ & TGGCGCTATGATGAAATCTGGAATGTT & 150 & {$[85]$} \\
\hline & Vir 2052 R & TACGATGTTGTCGTCGCCGATGAA & & \\
\hline \multirow[t]{6}{*}{ Flavivirus NS5 } & Flavi JV2a F & AGYMGHGCCATHTGGTWCATGTGG & 150 & [83] \\
\hline & Flavi JV2b F & AGCCGYGCCATHTGGTATATGTGG & & \\
\hline & Flavi JV2C F & AGYCGMGCAATHTGGTACATGTGG & & \\
\hline & Flavi JV2d F & AGTAGAGCTATATGGTACATGTGG & & \\
\hline & Flavi JV2a R & GTRTCCCADCCDGCDGTRTCATC & & \\
\hline & Flavi JV2b R & GTRTCCCAKCCWGCTGTGTCGTC & & \\
\hline \multirow[t]{2}{*}{ Orthobunyavirus NP (s-segment) } & Bunyagroup F & CTGCTAACACCAGCAGTACTTTTGAC & 210 & {$[86]$} \\
\hline & Bunyagroup $\mathrm{R}$ & TGGAGGGTAAGACCATCGTCAGGAACTG & & \\
\hline \multirow[t]{2}{*}{ Dhori virus NP } & Dhori F & CGAGGAAGAGCAAAGGAAAG & 200 & {$[83]$} \\
\hline & Dhori R & GTGCGCCCCTCTGGGGTTT & & \\
\hline \multirow[t]{2}{*}{ Thogoto virus (M-segment) } & Thogoto S6 F & GATGACAGYCCTTCTGCAGTGGTGT & 200 & {$[83]$} \\
\hline & Thogoto S6 R & RACTTTRTTGCTGACGTTCTTGAGGAC & & \\
\hline \multirow[t]{2}{*}{ Rickettsia 165 rRNA } & Rick-F & GAACGCTATCGGTATGCTTAACACA & 364 & {$[87]$} \\
\hline & Rick-R & CATCACTCACTCGGTATTGCTGGA & & \\
\hline \multirow[t]{2}{*}{ Theileria and Babesia 18S rRNA } & RLB-F & GAGGTAGTGACAAGAAATAACAATA & 450 & {$[88]$} \\
\hline & RLB-R & TCTTCGATCCCCTAACTTTC & & \\
\hline \multirow[t]{2}{*}{ Anaplasma 165 rRNA } & AnaplasmaJV F & CGGTGGAGCATGTGGTTTAATTC & 300 & {$[71]$} \\
\hline & AnaplasmaJV R & CGRCGTTGCAACCTATTGTAGTC & & \\
\hline \multirow[t]{2}{*}{ Ehrlichia $16 \mathrm{~S}$ rRNA } & Ehrlichia 16S F & CGTAAAGGGCACGTAGGTGGACTA & 200 & {$[89]$} \\
\hline & Ehrlichia 16S R & CACCTCAGTGTCAGTATCGAACCA & & \\
\hline \multirow[t]{3}{*}{ Anaplasma/Ehrlichia 16S rRNA } & EHR16SD & GGTACCYACAGAAGAAGTCC & 1090 & [90-92] \\
\hline & pH 1522 & AAGGAGGTGATCCAGCCGCA & & \\
\hline & pH 1492 & GGCTACCTTGTTACGACTT & & \\
\hline
\end{tabular}

visualized by $1.5 \%$ agarose gel electrophoresis and representative amplicons were purified (Exo 1-rSAP, Biolabs, UK) and sequenced in both directions at Macrogen (The Netherlands).

\section{Phylogenetic analysis}

Sequences were inspected and edited in Geneious prime version 2019.0.4 software (created by Biomatters, Auckland, New Zealand). Sequence contigs were then queried against known sequences in the GenBank $\mathrm{nr}$ database (http://www.ncbi. nlm.nih.gov/) using
BLAST to confirm their identity and relation to existing deposited sequences [93]. Study sequences were then aligned with related pathogen sequences available in the GenBank nr database using the MAFFT plugin in Geneious Prime software version 2020.2.2 [94]. Maximum-likelihood phylogenies were constructed using PhyML v. 3.0 with automatic model selection based on Akaike information criterion. Tree topologies were estimated over 1000 bootstrap replicates with nearest neighbour interchange improvements [95]. Trees were visualized and edited in FigTree 1.4.4 [96]. 


\section{Statistical analysis}

Logistic regression in $R^{\circledR}$ version 4.0.3 was performed using cattle breed, sex, age, body condition score, presence/absence of ticks, and sampling site as predictor variables, and the PCR-based positivity of cattle to Anaplasma spp., Ehrlichia spp., Theileria spp., and A. marginale as the response variables. Based on the metadata accompanying each sample, cattle breed was recoded into three levels for the analysis; animals recorded as zebu, indigenous, shorthorn, or shorthorn $\mathrm{x}$ zebu were classified as local, animals recorded as local $\mathrm{x}$ grade were classified as cross, and animals recorded as grade or exotic were classified as exotic. Sex (male/female) was used as recorded, while age, recorded as a continuous variable in months, was dichotomized into cattle less than 12 months old, and cattle aged 12 months and above. Body condition score, which was recorded on a scale of 1 (thin) to 5 (obese), was dichotomized into 1-2.5 (lower range) and 3-5 (upper range). Tick presence or absence, which was determined by visual inspection of predilection sites, was kept as recorded (Yes/No) for the analysis. Sampling site (LM/SH) was used as recorded.

The association of these variables with TBP occurrence was determined by estimating odds ratios, confidence intervals, and $P$-values. We first performed univariable analysis between the predictor variables and each of the TBP concerned, and then selected all the variables with a univariable likelihood ratio test $P$-value $<0.1$ for inclusion into the multivariable models. In the multivariable model a Wald $P$-value of $<0.05$ was considered statistically significant.

\section{Abbreviations}

TBP: Tick-borne pathogen„ TBD: Tick-borne disease; CCHF: Crimean-Congo haemorrhagic fever; LM: Livestock market; SH: Slaughterhouse; PCR-HRM: Polymerase chain reaction-high resolution melting; ICIPE: International Centre of Insect Physiology and Ecology; ML-EID: Martin Lüscher Emerging Infectious Diseases; ILRI: International Livestock Research Institute; IREC: Institutional Animal Care and Use Committee; Cl: Confidence interval; OR: Odds ratio; DNA: Deoxyribonucleic acid; RNA: Ribonucleic acid; cDNA: Complementary deoxyribonucleic acid; BLAST: Basic Local Alignment Search Tool; MAFFT: Multiple alignment using fast Fourier transform; dNTPs: deoxyribonucleotide triphosphate; 165 rRNA: 165 ribosomal ribonucleic acid; 18 S rRNA: 18 S ribosomal ribonucleic acid; NACOSTI: National Commission for Science, Technology and Innovation.
}

\section{Acknowledgements}

We acknowledge the Zoonoses in Livestock in Kenya (ZooLinK) team for collection of blood samples. We also acknowledge the assistance rendered by Samuel Njoroge, Lydiah Mueni, Lynn Kirwa, and Christian Odinga in retrieving the relevant samples from the ZooLinK bio-bank and associated metadata. We also acknowledge Dr. Bester T. Mudereri of icipe's Data Management Modelling and Geo-information unit for assistance in producing the study site map.

\section{Authors' contributions}

LCF, MKM, TC, LW, JV, DKM, and EMF designed the study and sampling. TC and DOO performed the laboratory work. TC and JV analysed the results. TC wrote the original manuscript while JV, DKM, EMF, LW, DOO, LCF, MKM, and ADSB edited and reviewed the manuscript. All the authors read and approved the final manuscript.

\section{Funding}

This study received financial support from following organizations and agencies: The ZooLinK project was supported by the Biotechnology and Biological Sciences Research Council, the Department for International Development, the Economic \& Social Research Council, the Medical Research Council, the Natural Environment Research Council and the Defence Science \& Technology Laboratory, under the Zoonoses and Emerging Livestock Systems (ZELS) programme, grant reference BB/L019019/1. It also received support from the CGIAR Research Program on Agriculture for Nutrition and Health $(\mathrm{A} 4 \mathrm{NH})$, led by the International Food Policy Research Institute (IFPRI). We also acknowledge the CGIAR Fund Donors (http://www.cgiar.org/funde rs/); the study also received support from the European Union's Integrated Biological Control Applied Research Program (EU-IBCARP) (grant number: DCI-FOOD/2014/346-739) and icipe institutional funding from UK's Foreign, Commonwealth \& Development Office (FCDO); Swedish International Development Cooperation Agency (Sida); the Swiss Agency for Development and Cooperation (SDC); Federal Democratic Republic of Ethiopia; and the Kenyan Government. Tatenda Chiuya was supported by a German Academic Exchange Service (DAAD) through the icipe ARPPIS-DAAD scholarship and through a University of Pretoria postgraduate bursary. The funders had no role in the design, data collection, interpretation, or decision to submit this publication.

\section{Availability of data and materials}

The dataset generated and analysed in this study can be made available from the corresponding authors on reasonable request. All the nucleotide sequences generated from this study have been deposited and are available in the GenBank database under the accession numbers indicated in text.

\section{Declarations}

\section{Ethics approval and consent to participate}

This study was approved by the ILRI Institutional Animal Care and Use Committee (ref IACUC-RC2017-04). Data from the owners of livestock were collected after approval by the ILRI Institutional Research Ethics Committee (ref ILRI-IREC2017-08/2). Both committees are licensed by the National Commission for Science, Technology and Innovation (NACOSTI) in Kenya and approved by the Federalwide Assurance for the Protection of Human Subjects in the USA. Informed and signed consent was obtained from the owner/ custodians of the sampled animals. Sampling was performed by a veterinarian and was facilitated by market chairpersons and handlers.

\section{Consent for publication}

Not applicable.

\section{Competing interests}

The authors declare that they have no competing interests.

\section{Author details}

${ }^{1}$ International Centre of Insect Physiology and Ecology (icipe), P.O Box 30772-00100, Nairobi, Kenya. ${ }^{2}$ Department of Zoology and Entomology, University of Pretoria, Private Bag 20, Pretoria 0028, South Africa. ${ }^{3}$ International Livestock Research Institute, Old Naivasha Road, P.O Box 30709, Nairobi 00100, Kenya. ${ }^{4}$ Institute of Infection, Veterinary and Ecological Sciences, University of Liverpool, Leahurst Campus, Chester High Road, Neston CH64 7TE, UK.

Received: 25 May 2021 Accepted: 5 November 2021

Published online: 27 November 2021

\section{References}

1. Jongejan F, Uilenberg G. The global importance of ticks. Parasitology. 2004;129(Suppl:S3-14). https://doi.org/10.1017/s0031182004005967.

2. Abanda B, Paguem A, Abdoulmoumini M, Kingsley MT, Renz A, Eisenbarth A. Molecular identification and prevalence of tick-borne 
pathogens in zebu and taurine cattle in North Cameroon. Parasit Vectors. 2019;12(1):448. https://doi.org/10.1186/s13071-019-3699-x.

3. Adjou Moumouni PF, Aboge GO, Terkawi MA, Masatani T, Cao S, Kamyingkird K, et al. Molecular detection and characterization of Babesia bovis, Babesia bigemina, Theileria species and Anaplasma marginale isolated from cattle in Kenya. Parasit Vectors. 2015;8(1):496. https://doi.org/10. 1186/s13071-015-1106-9.

4. Gachohi J, Skilton R, Hansen F, Ngumi P, Kitala P. Epidemiology of East Coast fever (Theileria parva infection) in Kenya: past, present and the future. Parasit Vectors. 2012;5(1):194. https://doi.org/10.1186/ 1756-3305-5-194.

5. Okuthe OS, Buyu GE. Prevalence and incidence of tick-borne diseases in smallholder farming systems in the western-Kenya highlands. Vet Parasitol. 2006;141(3-4):307-12.

6. Wesonga FD, Kitala PM, Gathuma JM, Njenga MJ, Ngumi PN. An assessment of tick-borne diseases constraints to livestock production in a smallholder livestock production system in Machakos District, Kenya. Livest Res Rural Dev. 2010;22(6):111.

7. Njiiri NE, Bronsvoort BM dC, Collins NE, Steyn HC, Troskie M, Vorster I, et al. The epidemiology of tick-borne haemoparasites as determined by the reverse line blot hybridization assay in an intensively studied cohort of calves in western Kenya. Vet Parasitol. 2015;210(1-2):69-76. https://doi. org/10.1016/j.vetpar.2015.02.020.

8. Mattioli RC, Pandey VS, Murray M, Fitzpatrick JL. Immunogenetic influences on tick resistance in African cattle with particular reference to trypanotolerant N'Dama (Bos taurs) and trypanosusceptible Gobra zebu (Bos indicus) cattle. Acta Trop. 2000;75(3):263-77. https://doi.org/10.1016/ s0001-706x(00)00063-2.

9. Lorusso V, Wijnveld M, Majekodunmi AO, Dongkum C, Fajinmi A, Dogo $A G$, et al. Tick-borne pathogens of zoonotic and veterinary importance in Nigerian cattle. Parasit Vectors. 2016;9(1):217. https://doi.org/10.1186/ s13071-016-1504-7.

10. Thumbi SM, Bronsvoort BMDC, Poole EJ, Kiara H, Toye PG, Mbole-Kariuki $\mathrm{MN}$, et al. Parasite co-infections and their impact on survival of indigenous cattle. PLoS One. 2014;9(2):e76324. https://doi.org/10.1371/journal. pone.0076324.

11. Dantas-Torres F, Chomel BB, Otranto D. Ticks and tick-borne diseases: a one health perspective. Trends Parasitol. 2012;28(10):437-46. https://doi. org/10.1016/j.pt.2012.07.003.

12. Brouqui P, Bacellar F, Baranton G, Birtles RJ, Bjoërsdorff A, Blanco JR, et al. Guidelines for the diagnosis of tick-borne bacterial diseases in Europe. Clin Microbiol Infect. 2004;10(12):1108-32. https://doi.org/10.1111/j.14690691.2004.01019.x.

13. Ismail N, Bloch KC, McBride JW. Human ehrlichiosis and anaplasmosis. Clin Lab Med. 2011;30(1):261-92. https://doi.org/10.1016/j.cll.2009.10.004.

14. Breitschwerdt EB, Hegarty BC, Qurollo BA, Saito TB, Maggi RG, Blanton LS. Intravascular persistence of Anaplasma platys, Ehrlichia chaffeensis, and Ehrlichia ewingii DNA in the blood of a dog and two family members. Parasit Vectors. 2014;7:298. https://doi.org/10.1186/1756-3305-7-298.

15. Chochlakis D, loannou I, Sharif L, Kokkini S, Hristophi N, Dimitriou T, et al. Prevalence of Anaplasma sp. in goats and sheep in Cyprus. Vector-Borne Zoonotic Dis. 2009;9(5):457-63. https://doi.org/10.1089/vbz.2008.0019.

16. Maggi RG, Mascarelli PE, Havenga $L N$, Naidoo V, Breitschwerdt EB. Co-infection with Anaplasma platys, Bartonella henselae and Candidatus Mycoplasma haematoparvum in a veterinarian. Parasit Vectors. 2013;6:103. https://doi.org/10.1186/1756-3305-6-103.

17. Jensenius M, Davis X, Von Sonnenburg F, Schwartz E, Keystone JS, Leder $\mathrm{K}$, et al. Multicenter GeoSentinel analysis of rickettsial diseases in international travelers, 1996-2008. Emerg Infect Dis. 2009;15(11):1791-8. https:// doi.org/10.3201/eid1511.090677.

18. Kelly P, Matthewman L, Beati L, Raoult D, Mason P, Dreary M, et al. African tick-bite fever: a new spotted fever group rickettsiosis under an old name. Lancet. 1992;340(8825):982-3. https://doi.org/10.1016/0140-6736(92) 92878-j.

19. Ndip LM, Bouyer DH, Travassos APA, Rosa D, Titanji VPK, Tesh RB, et al. Acute spotted fever rickettsiosis among febrile patients, Cameroon. Emerg Infect Dis. 2004;10(3):432-7. https://doi.org/10.3201/eid1003. 020713.

20. Ergonul O. Crimean-Congo hemorrhagic fever virus: new outbreaks, new discoveries. Curr Opin Virol. 2012;2(2):215-20. https://doi.org/10.1016/j. coviro.2012.03.001.
21. Dunster L, Dunster M, Ofula V, Beti D, Kazooba-Voskamp F, Burt F, et al. First documentation of human Crimean-Congo hemorrhagic fever, Kenya. Emerg Infect Dis. 2002;8(9):1005-6. https://doi.org/10.3201/eid08 09.010510 .

22. Mirembe BB, Musewa A, Kadobera D, Kisaakye E, Birungi D, Eurien D, et al. Sporadic outbreaks of Crimean-Congo haemorrhagic fever in Uganda, July 2018-January 2019. PLoS Negl Trop Dis. 2021;15(3):e0009213. https:// doi.org/10.1371/journal.pntd.0009213.

23. Johnson N, Paul Phipps L, McFadzean H, Barlow AM. An outbreak of bovine babesiosis in February, 2019, triggered by above average winter temperatures in southern England and co-infection with Babesia divergens and Anaplasma phagocytophilum. Parasit Vectors. 2020;13(1):305. https://doi.org/10.1186/s13071-020-04174-3.

24. Koh FX, Panchadcharam C, Sitam FT, Tay ST. Molecular investigation of Anaplasma spp. in domestic and wildlife animals in peninsular Malaysia. Vet Parasitol Reg Stud Reports. 2018;13:141-7. https://doi.org/10.1016/j. vprsr.2018.05.006.

25. Peter SG, Aboge GO, Kariuki HW, Kanduma EG, Gakuya DW, Maingi N, et al. Molecular prevalence of emerging Anaplasma and Ehrlichia pathogens in apparently healthy dairy cattle in peri-urban Nairobi, Kenya. BMC Vet Res. 2020;16(1):364. https://doi.org/10.1186/s12917-020-02584-0.

26. Chiuya T, Masiga DK, Falzon LC, Bastos ADS, Fèvre EM, Villinger J. Tickborne pathogens, including Crimean-Congo haemorrhagic fever virus, at livestock markets and slaughterhouses in western Kenya. Transbound Emerg Dis. 2020. https://doi.org/10.1111/tbed.13911 Epub ahead of print.

27. Spengler JR, Bergeron É, Rollin PE. Seroepidemiological studies of Crimean-Congo hemorrhagic fever virus in domestic and wild animals. PLoS Negl Trop Dis. 2016;10(1):e0004210. https://doi.org/10.1371/journal. pntd.0004210.

28. Onono JO, Wieland B, Rushton J. Productivity in different cattle production systems in Kenya. Trop Anim Health Prod. 2012;45(1):423-30. https:// doi.org/10.1007/s11250-012-0233-y.

29. Kenya National Bureau of Statistics. Livestock population. 2013; Available from: https://www.knbs.or.ke/livestock-population/.

30. Wesonga FD, Gachohi JM, Kitala PM, Gathuma JM, Njenga MJ. Seroprevalence of Anaplasma marginale and Babesia bigemina infections and associated risk factors in Machakos County, Kenya. Trop Anim Health Prod. 2017:49(2):265-72. https://doi.org/10.1007/s11250-016-1187-2.

31. Wesonga FD, Gachohi JM, Kitala PM, Gathuma JM, Njenga MJ. Theileria parva infection seroprevalence and associated risk factors in cattle in Machakos County, Kenya. Trop Anim Health Prod. 2014;47(1):93-101. https://doi.org/10.1007/s11250-014-0690-6.

32. de Clare Bronsvoort BM, Thumbi SM, Poole EJ, Kiara H, Auguet OT, Handel IG, et al. Design and descriptive epidemiology of the infectious diseases of east African livestock (IDEAL) project, a longitudinal calf cohort study in western Kenya. BMC Vet Res. 2013;9. https://doi.org/10.1186/ 1746-6148-9-171.

33. Okal MN, Odhiambo BK, Otieno P, Bargul JL, Masiga D, Villinger J, et al. Anaplasma and Theileria pathogens in cattle of Lambwe valley, Kenya: a case for pro-active surveillance in the wildlife-livestock interface. Microorganisms. 2020;8(11):1830. https://doi.org/10.3390/microorganisms8 111830.

34. Ahmed S, Dávila JD, Allen A, Haklay M, Tacoli C, Fèvre EM. Does urbanization make emergence of zoonosis more likely? Evidence, myths and gaps. Environ Urban. 2019;31(2):443-60. https://doi.org/10.1177/0956247819 866124.

35. Morse SS. Factors in the emergence of infectious diseases. Emerg Infect Dis. 1995;1 (1):7-15. https://doi.org/10.3201/eid0101.950102.

36. Fèvre EM, De GWA, Thomas LF, Cook EAJ, Kariuki S, Wamae CN. An integrated study of human and animal infectious disease in the Lake Victoria crescent small-holder crop-livestock production system, Kenya. BMC Infect Dis. 2017;17(1):457. https://doi.org/10.1186/s12879-017-2559-6.

37. Nyaruaba R, Mwaliko C, Mwau M, Mousa S, Wei H. Arboviruses in the east African community partner states: a review of medically important mosquito-borne arboviruses. Pathog Glob Health. 2019;113(5):209-28. https://doi.org/10.1080/20477724.2019.1678939.

38. Fèvre EM, Bronsvoort BMDC, Hamilton KA, Cleaveland S. Animal movements and the spread of infectious diseases. Trends Microbiol. 2006;14(3):125-31. https://doi.org/10.1016/j.tim.2006.01.004.

39. Cruz AC, Zweygarth E, Ribeiro MFB, Da Silveira JAG, De La Fuente J, Grubhoffer L, et al. New species of Ehrlichia isolated from Rhipicephalus 
(Boophilus) microplus shows an ortholog of the E. canis major immunogenic glycoprotein gp36 with a new sequence of tandem repeats. Parasit Vectors. 2012;5(1):291. https://doi.org/10.1186/1756-3305-5-291.

40. Byaruhanga C, Collins NE, Knobel DL, Khumalo ZTH, Chaisi ME, Oosthuizen MC. Molecular detection and phylogenetic analysis of Anaplasma marginale and Anaplasma Centrale amongst transhumant cattle in NorthEastern Uganda. Ticks Tick Borne Dis. 2018;9(3):580-8. https://doi.org/10. 1016/j.ttbdis.2018.01.012.

41. Zhou Z, Wu Y, Chen Y, Wang Z, Hu S, Zhou R. Molecular and serological prevalence of toxoplasma gondii and Anaplasma spp. infection in goats from Chongqing municipality. Parasite. 2018;25:20. https://doi.org/10. 1051/parasite/2018024.

42. Guo WP, Zhang B, Wang YH, Xu G, Wang X, Ni X, et al. Molecular identification and characterization of Anaplasma capra and Anaplasma platys-like in Rhipicephalus microplus in Ankang, Northwest China. BMC Infect Dis. 2019;19(1):434. https://doi.org/10.1186/s12879-019-4075-3.

43. Yan Y, Jiang Y, Tao D, Zhao A, Qi M, Ning C. Molecular detection of Anaplasma spp. in dairy cattle in southern Xinjiang, China. Vet Parasitol Reg Stud Rep. 2020;20:100406. https://doi.org/10.1016/j.vprsr.2020.100406.

44. Glidden CK, Koehler AV, Hall RS, Saeed MA, Coppo M, Beechler BR, et al. Elucidating cryptic dynamics of Theileria communities in African buffalo using a high - throughput sequencing informatics approach. Ecol Evol. 2020;10(1):70-80. https://doi.org/10.1002/ece3.5758.

45. Knowles DP, Kappmeyer LS, Haney D, Herndon DR, Fry LM, Munro JB, et al. Discovery of a novel species, Theileria haneyi $\mathrm{n}$. sp ., infective to equids, highlights exceptional genomic diversity within the genus Theileria : implications for apicomplexan parasite surveillance. Int J Parasitol. 2018;48(9-10):679-90. https://doi.org/10.1016/j.jpara.2018.03.010.

46. Oundo JW, Villinger J, Jeneby M, Ong'amo G, Otiende MY, Makhulu EE, et al. Pathogens, endosymbionts, and blood-meal sources of host-seeking ticks in the fast-changing Maasai Mara wildlife ecosystem. PLoS One. 2020;15(8):e0228366. https://doi.org/10.1371/journal.pone.0228366.

47. Martins TM, Neves L, Pedro OC, Fafetine JM, Do Rosário VE, Domingos A. Molecular detection of Babesia spp. and other haemoparasitic infections of cattle in Maputo province, Mozambique. Parasitology. 2010;137(6):939-46. https://doi.org/10.1017/S003118200999196X.

48. Byaruhanga C, Collins NE, Knobel D, Chaisi ME, Vorster I, Steyn HC, et al. Molecular investigation of tick-borne haemoparasite infections among transhumant zebu cattle in Karamoja region, Uganda. Vet Parasitol Reg Stud Rep. 2016;3-4:27-35. https://doi.org/10.1016/j.vprsr.2016.06.004.

49. Katende J, Morzaria S, Toye P, Skilton R, Nene V, Nkonge C, et al. An enzyme-linked immunosorbent assay for detection of Theileria parva antibodies in cattle using a recombinant polymorphic immunodominant molecule. Parasitol Res. 1998;84(5):408-16. https://doi.org/10.1007/s0043 60050419.

50. Eygelaar D, Jori F, Mokopasetso M, Sibeko KP, Collins NE, Vorster I. Tickborne haemoparasites in African buffalo ( Syncerus caffer) from two wildlife areas in northern Botswana. Parasit Vectors. 2015;8:26. https://doi. org/10.1186/s13071-014-0627-y.

51. Muhanguzi D, Picozzi K, Hatendorf J, Thrusfield M, Welburn SC, Kabasa JD, et al. Prevalence and spatial distribution of Theileria parva in cattle under crop-livestock farming systems in Tororo District, Eastern Uganda. Parasit Vectors. 2014;7:91. https://doi.org/10.1186/1756-3305-7-91.

52. Homewood K, Trench P, Randall S, Lynen G, Bishop B. Livestock health and socio-economic impacts of a veterinary intervention in Maasailand: infection-and-treatment vaccine against East Coast fever. Agric Syst. 2006;89(2-3):248-71. https://doi.org/10.1016/j.agsy.2005.09.004.

53. Byaruhanga C, Oosthuizen MC, Collins NE, Knobel D. Using participatory epidemiology to investigate management options and relative importance of tick-borne diseases amongst transhumant zebu cattle in Karamoja region, Uganda. Prev Vet Med. 2015;122(3):287-97. https://doi. org/10.1016/j.prevetmed.2015.10.011.

54. Hailemariam Z, Krücken J, Baumann M, Ahmed JS, Clausen PH, Nijhof AM. Molecular detection of tick-borne pathogens in cattle from southwestern Ethiopia. PLoS One. 2017;12(11):e0188248. https://doi.org/10.1371/journ al.pone. 0188248 .

55. Zhou Z, Li K, Sun Y, Shi J, Li H, Chen Y, et al. Molecular epidemiology and risk factors of Anaplasma spp., Babesia spp. and Theileria spp. infection in cattle in Chongqing, China. PLoS One. 2019;14(7):e0215585. https://doi. org/10.1371/journal.pone.0215585.
56. Kocan KM. Targeting ticks for control of selected hemoparasitic diseases of cattle. Vet Parasitol. 1995;57(1-3):121-51. https://doi.org/10. 1016/0304-4017(94)03116-e.

57. Lake Victoria Basin Commission, GRID-Arendal. Lake Victoria Basin: Atlas of our Changing Environment. GRID-Arendal; 2017: 36. Available from: https://www.grida.no/publications/328.

58. Sivakumar T, Hayashida K, Sugimoto C, Yokoyama N. Evolution and genetic diversity of Theileria. Infect Genet Evol. 2014;27:250-63. https:// doi.org/10.1016/j.meegid.2014.07.013.

59. Woolhouse MEJ, Thumbi SM, Jennings A, Chase-Topping M, Callaby $\mathrm{R}$, Kiara $\mathrm{H}$, et al. Co-infections determine patterns of mortality in a population exposed to parasite infection. Sci Adv. 2015;1 (2):e1400026. https://doi.org/10.1126/sciadv.1400026.

60. Cox FEG. Concomitant infections, parasites and immune responses. Parasitology. 2001;122(S23-38). https://doi.org/10.1017/s003118200 001698x.

61. Krause PJ. Human babesiosis. Int J Parasitol. 2019;49(2):165-74. https:// doi.org/10.1016/j.ijpara.2018.11.007.

62. Ringo AE, Adjou Moumouni PF, Lee SH, Liu M, Khamis YH, Gao Y, et al. Molecular detection and characterization of tick-borne protozoan and rickettsial pathogens isolated from cattle on Pemba Island, Tanzania. Ticks Tick Borne Dis. 2018;9(6):1437-45. https://doi.org/10.1016/j.ttbdis. 2018.06.014

63. Arraga-alvarado CM, Qurollo BA, Parra OC, Berrueta MA, Hegarty BC, Breitschwerdt EB. Case Report : molecular evidence of Anaplasma platys infection in two women from Venezuela. Am J Trop Med Hyg. 2014;91(6):1161-5. https://doi.org/10.4269/ajtmh.14-03722014.

64. Ben Said M, Belkahia H, El Mabrouk N, Saidani M, Alberti A, Zobba R, et al. Anaplasma platys-like strains in ruminants from Tunisia. Infect Genet Evol. 2017;49:226-33. https://doi.org/10.1016/j.meegid.2017.01. 023.

65. Muinde P, Bettridge JM, Sousa FM, Dürr S, Dohoo IR, Berezowski J, et al. Who let the dogs out? Exploring the spatial ecology of free-roaming domestic dogs in western Kenya. Ecol Evol. 2021;11(9):4218-31. https:// doi.org/10.1002/ece3.7317.

66. Cabezas-Cruz A, Zweygarth E, Vancová M, Broniszewska M, Grubhoffer L, Passos LMF, et al. Ehrlichia minasensis sp. nov., isolated from the tick Rhipicephalus microplus. Int J Syst Evol Microbiol. 2016;66(3):1426-30. https:// doi.org/10.1099/ijsem.0.000895.

67. de Aguiar DM, Junior JPA, Nakazato L, Bard E, Aguilar-Bultet L, Vorimore $F$, et al. Isolation and characterization of a novel pathogenic strain of Ehrlichia minasensis. Microorganisms. 2019;7(11):528. https://doi.org/10. 3390/microorganisms7110528.

68. Norval RAI, Perry BD, Young AS, Lawrence JA, Mukhebi AW, Bishop R, et al. The epidemiology of theileriosis in Africa. London, UK: Academic Press; 1992.

69. Magona JW, Walubengo J, Olaho-Mukani W, Jonsson NN, Welburn SW, Eisler MC. Spatial variation of tick abundance and seroconversion rates of indigenous cattle to Anaplasma marginale, Babesia bigemina and Theileria parva infections in Uganda. Exp Appl Acarol. 2011;55(2):203-13. https:// doi.org/10.1007/s10493-011-9456-2.

70. Andrew HR, Norval RAI. The carrier status of sheep, cattle and African buffalo recovered from heartwater. Vet Parasitol. 1989;34(3):261-6. https:// doi.org/10.1016/0304-4017(89)90056-3.

71. Mwamuye MM, Kariuki E, Omondi D, Kabii J, Odongo D, Masiga D, et al. Novel Rickettsia and emergent tick-borne pathogens: a molecular survey of ticks and tick-borne pathogens in Shimba Hills National Reserve, Kenya. Ticks Tick Borne Dis. 2017;8(2):208-18. https://doi.org/10.1016/j. ttbdis.2016.09.002.

72. Omondi D, Masiga DK, Fielding BC, Kariuki E, Ajamma YU, Mwamuye MM, et al. Molecular detection of tick-borne pathogen diversities in ticks from livestock and reptiles along the shores and adjacent islands of Lake Victoria and Lake Baringo, Kenya. Front Vet Sci. 2017;4:73. https://doi.org/ 10.3389/fvets.2017.00073.

73. Younan M, Ouso D, Bodha B, Keitany EK, Wesonga HO, Satiwa R, et al. Ehrlichia spp. close to Ehrlichia ruminantium, Ehrlichia canis, and "Candidatus Ehrlichia regneryi" linked to heartwater-like disease in Kenyan camels (Camelus dromedarius). Trop Anim Heal Prod. 2021;53(1):147. https://doi. org/10.1007/s11250-020-02524-y. 
74. Allsopp MT, Louw M, Meyer EC. Ehrlichia ruminantium: an emerging human pathogen? Ann N Y Acad Sci. 2005;1063:358-60. https://doi.org/ 10.1196/annals.1355.060.

75. Monje LD, Costa FB, Colombo VC, Labruna MB, Antoniazzi LR, Gamietea I, et al. Dynamics of exposure to Rickettsia parkeri in cattle in the Paraná river delta, Argentina. J Med Entomol. 2016;53(3):660-5. https://doi.org/ 10.1093/jme/tjv250.

76. Gu W, Unnasch TR, Katholi CR, Lampman R, Novak RJ. Fundamental issues in mosquito surveillance for arboviral transmission. Trans R Soc Trop Med Hyg. 2008;102(8):817-22. https://doi.org/10.1016/j.trstmh.2008.03.019.

77. Chiuya T, Masiga DK, Falzon LC, Bastos ADS, Fèvre EM, Villinger J. A survey of mosquito-borne and insect-specific viruses in hospitals and livestock markets in western Kenya. PLoS One. 2021;16(5):e0252369. https://doi. org/10.1371/journal.pone.0252369.

78. Gwee SXW, St John AL, Gray GC, Pang J. Animals as potential reservoirs for dengue transmission: a systematic review. One Health. 2021;12:100216. https://doi.org/10.1016/j.onehlt.2021.100216.

79. Guilherme JM, Gonella-Legall C, Legall F, Nakoume E, Vincent J. Seroprevalence of five arboviruses in zebu cattle in the Central African Republic. Trans R Soc Trop Med Hyg. 1996;90(1):31-3. https://doi.org/10. 1016/s0035-9203(96)90468-X.

80. Falzon LC, Alumasa L, Amanya F, Kang'ethe E, Kariuki S, Momanyi K, et al. One health in action: operational aspects of an integrated surveillance system for zoonoses in western Kenya. Front Vet Sci. 2019;6:252. https:// doi.org/10.3389/fvets.2019.00252.

81. Falzon LC, Ogola JG, Odinga CO, Naboyshchikov L, Fèvre EM, Berezowski J. Electronic data collection to enhance disease surveillance at the slaughterhouse in a smallholder production system. Sci Rep. 2021;11(1):19447. https://doi.org/10.1038/s41598-021-98495-7.

82. Fèvre EM, Tilley A, Picozzi K, Fyfe J, Anderson I, Magona JW, et al. Central point sampling from cattle in livestock markets in areas of human sleeping sickness. Acta Trop. 2006;97(2):229-32. https://doi.org/10.1016/j.actat ropica.2005.11.005.

83. Villinger J, Mbaya MK, Ouso D, Kipanga PN, Lutomiah J, Masiga DK. Arbovirus and insect-specific virus discovery in Kenya by novel six genera multiplex high-resolution melting analysis. Mol Ecol Resour. 2017;17(3):466-80. https://doi.org/10.1111/1755-0998.12584.

84. Endoh D, Mizutani T, Kirisawa R, Maki Y, Saito H, Kon Y, et al. Species-independent detection of RNA virus by representational difference analysis using non-ribosomal hexanucleotides for reverse transcription. Nucleic Acids Res. 2005;33(6):e65. https://doi.org/10.1093/nar/gni064.

85. Eshoo MW, Whitehouse CA, Zoll ST, Massire C, Pennella TTD, Blyn LB, et al. Direct broad-range detection of alphaviruses in mosquito extracts. Virology. 2007;368(2):286-95. https://doi.org/10.1016/j.virol.2007.06.016.

86. Lambert AJ, Lanciotti RS. Consensus amplification and novel multiplex sequencing method for $\mathrm{S}$-segment species identification of 47 viruses of the Orthobunyavirus, Phlebovirus, and Nairovirus genera of the family Bunyaviridae. J Clin Microbiol. 2009;47(8):2398-404. https://doi.org/10. 1128/JCM.00182-09.

87. Nijhof ARDM, Bodaan C, Postigo M, Nieuwenhuijs H, Opsteegh M, Franssen $\mathrm{L}$, et al. Ticks and associated pathogens collected from domestic animals in the Netherlands. Vector Borne Zoonotic Dis. 2007;7(4):585-95. https://doi.org/10.1089/vbz.2007.0130.

88. Georges K, Loria GR, Riili S, Greco A, Caracappa S, Jongejan F, et al. Detection of haemoparasites in cattle by reverse line blot hybridisation with a note on the distribution of ticks in Sicily. Vet Parasitol. 2000;99(4):273-86. https://doi.org/10.1016/s0304-4017(01)00488-5.

89. Tokarz R, Kapoor V, Samuel JE, Bouyer DH, Briese T, Lipkin WI. Detection of tick-borne pathogens by masstag polymerase chain reaction. VectorBorne Zoonotic Dis. 2009;9(2):147-51. https://doi.org/10.1089/vbz.2008. 0088.

90. Parola P, Roux V, Camicas JL, Baradji I, Brouqui P, Raoult D. Detection of ehrlichiae in African ticks by polymerase chain reaction. Trans $\mathrm{R}$ Soc Trop Med Hyg. 2000;94(6):707-8. https://doi.org/10.1016/s0035-9203(00) 90243-8.

91. Reysenbach AL, Giver LJ, Wickham GS, Pace NR. Differential amplification of rRNA genes by polymerase chain reaction. Appl Environ Microbiol. 1992;58(10):3417-8. https://doi.org/10.1128/AEM.58.10.3417-3418.1992.

92. Edwards U, Rogall T, Blöcker H, Emde M, Böttger EC. Isolation and direct complete nucleotide determination of entire genes. Characterization of a gene coding for $16 S$ ribosomal RNA. Nucleic Acids Res. 1989;17(19):784353. https://doi.org/10.1093/nar/17.19.7843.

93. Altschul SF, Gish W, Miller W, Myers EW, Lipman DJ. Basic local alignment search tool. J Mol Biol. 1990;215(3):403-10. https://doi.org/10.1016/ S0022-2836(05)80360-2.

94. Kearse M, Moir R, Wilson A, Stones-Havas S, Cheung M, Sturrock S, et al. Geneious basic: an integrated and extendable desktop software platform for the organization and analysis of sequence data. Bioinformatics. 2012:28(12):1647-9. https://doi.org/10.1093/bioinformatics/bts199.

95. Guindon S, Dufayard JF, Lefort V, Anisimova M, Hordijk W, Gascuel O. New algorithms and methods to estimate maximum-likelihood phylogenies: assessing the performance of PhyML 3.0. Syst Biol. 2010;59(3):307-21. https://doi.org/10.1093/sysbio/syq010.

96. Rambaut A. FigTree v 1.4.2. Edinburgh, UK: University of Edinburgh; 2014. Available at: http://tree.bio.ed.ac.uk/software/figtree/

\section{Publisher's Note}

Springer Nature remains neutral with regard to jurisdictional claims in published maps and institutional affiliations.

Ready to submit your research? Choose BMC and benefit from:

- fast, convenient online submission

- thorough peer review by experienced researchers in your field

- rapid publication on acceptance

- support for research data, including large and complex data types

- gold Open Access which fosters wider collaboration and increased citations

- maximum visibility for your research: over 100M website views per year

At BMC, research is always in progress.

Learn more biomedcentral.com/submissions 